\title{
„Trzy puzdra z kaftiorami...”, czyli o fajansie i porcelanie na tykocińskim zamku
}

\section{„Three cases with coffee-pots...", it is about faience and porcelan in \\ Tykocin castle}

Dotychczasowe prace archeologiczne prowadzone na zamku w podlaskim Tykocinie dostarczyły nie tylko licznego, ale i zróżnicowanego zbioru znalezisk ruchomych. Oprócz dominujących w nim przedmiotów lokalnej proweniencji występują także wyroby z odległych ośrodków produkcyjnych; są to między innymi fragmenty szklanych naczyń, glinianych fajek, elementy uzbrojenia i monety z okresu od XVI po XIX wiek. Niniejsze rozważania będą koncentrować się na dwóch wybranych kategoriach nowożytnych importów oraz na ich krajowych naśladownictwach, tzn. na porcelanie i fajansie. Obecność tych wyrobów na tykocińskim zamku ma związek z burzliwymi dziejami obiektu i losami jego dysponentów.

Tutejsze założenie funkcjonowało w trzech etapach i trzech formach: jako późnośredniowieczny gród (zapewne drewniany, zniszczony wskutek pożaru przed rokiem 1522 i najpewniej nie odbudowany), w miejscu którego wzniesiony został renesansowy, murowany zamek wraz z bastejowym systemem obronnym, z czasem (prawdopodobnie na początku XVII wieku) przekształcony w nowożytną, rozległą twierdzę bastionową. Przyjmuje się, że zasadniczy kres funkcjonowania obiektu nastąpił w 2. połowie XVIII wieku wraz z rozbiórką części murów zamkowych, dokonaną po decyzji ówczesnego właściciela.

Badania wykopaliskowe na terenie tego założenia zostały podjęte już w latach 1961-1963 przez grupę archeologów pod kierunkiem Jerzego Kruppé. Towarzyszyły one pracom architektonicznym i budowlanym, mającym na celu 
stworzenie z pozostałości zamku tzw. trwałej ruiny ${ }^{1}$. Kolejne prace archeologiczne prowadzone były przez autorów niniejszego artykułu od 2001 do 2007 roku$^{2}$.

Wśród około 91 tysięcy różnych kategorii źródeł pozyskanych z omawianego stanowiska wyróżniono 540 ułamków wyrobów fajansowych i 74 porcelanowych, co stanowi nikły odsetek, nieprzekraczający $1 \%$. Minimalną liczbę tych naczyń określono na 304, odpowiednio: 251 i 53 sztuki (tab. 1). Materiał charakteryzuje się na ogół fragmentarycznym stanem zachowania, tylko w niewielu przypadkach (19, w tym 6 egzemplarzy porcelanowych i 13 fajansowych, stanowiących 6,3\% ogółu) odtworzono wielkość całych naczyń i ich wymiary, co determinowało dalszą analizę i powodowało jej ograniczenia. Poza tym większość wyrobów nie jest niesygnowana, tym samym niełatwe było ustalenie ich pochodzenia oraz sprecyzowanie datowania. Sygnatury widnieją jedynie na 10 naczyniach (pięciu porcelanowych i pięciu fajansowych), z czego siedem w przybliżeniu można było zidentyfikować. Prawie połowę wszystkich materiałów (49\%) pozyskano z warstw przemieszanych, powstałych głównie wskutek prac architektonicznych prowadzonych na terenie założenia w latach 60 . ubiegłego wieku. $\mathrm{Z}$ takich nawarstwień pochodzi 57\% wyrobów porcelanowych i 47\% fajansowych.

Pomimo wskazanych niedostatków opisywane wyroby to interesujące, materialne świadectwa potrzeb i upodobań estetycznych nabywców, nowych trendów w ówczesnej produkcji ceramicznej oraz w zakresie konsumpcji, dowód realizacji zamówień zleceniodawców, a także czynnej wymiany towarowej między podlaskim Tykocinem a miastami nadbałtyckimi i stolicą w okresie nowożytnym.

Opisywane znaleziska to głównie elementy serwisów stołowych - talerze, talerzyki, misy i miseczki, filiżanki, wazy, jak również wazony i dzbany. Zestaw ten uzupełniają imbryk i pokrywki (zapewne od dzbanów). Ponadto w tykocińskim zbiorze znalazło się jedno naczynie sanitarne (nocnik). W kilku przypadkach, $\mathrm{z}$ uwagi na fragmentaryczny stan zachowania zabytków, nie określono ich rodzaju. Asortyment wyrobów fajansowych jest bogatszy w porównaniu z porcelanowymi, przy czym w obu grupach wyraźnie dominują talerze (tab. 1).

Talerze stanowią ponad dwie trzecie wszystkich wyrobów fajansowych i nieco ponad jedną czwartą porcelanowych (ryc. 1: 4, 7, 9; ryc. 2: 1-3, 6-7; ryc. 3: 2, 3; ryc. $4: 1-3,5$; ryc. $5: 2,4-6,8,10$ ). Służyły przede wszystkim do podawania potraw płynnych lub półpłynnych. Ich kołnierze są znacznie rozchylone w stosunku do pionowej osi, przeważnie wyraźnie oddzielone wrębem od lustra (brzuśca),

\footnotetext{
${ }^{1}$ Prace te miały charakter ratowniczy. Część znalezionych wówczas materiałów źródłowych pochodziła $\mathrm{z}$ warstw przemieszanych, zebranych podczas odsłaniania fundamentów zamku oraz z sondaży architektonicznych (Bis, Bis 2006, s. 221-226). Precyzyjne określenie miejsc odkrycia tych znalezisk oraz sekwencji stratygraficznej na ogół nie jest obecnie możliwe, dlatego też podstawą ich datowania jest głównie analiza formalno-typologiczna oraz analogie.

${ }^{2}$ Badania te poprzedziły rozpoznawcze odwierty geotechniczne prowadzone przez autorów artykułu w 1999 roku. Datowanie znalezisk z badań w latach 2001-2007 ustalono na podstawie sekwencji stratygraficznej skorelowanej z danymi historycznymi, datowaniem dendrochronologicznym próbek drewna i innymi, współwystępującymi ruchomymi materiałami źródłowymi.
} 
Tabela 1. Tykocin - zamek, woj. podlaskie. Rodzaje wyrobów porcelanowych i fajansowych

\begin{tabular}{|c|c|c|c|c|c|c|}
\hline \multirow{2}{*}{ rodzaje } & \multicolumn{3}{|c|}{ porcelanowe } & \multicolumn{2}{c|}{ fajansowe } & \multicolumn{2}{c|}{ Razem } \\
\cline { 2 - 5 } & liczba & procent & liczba & procent & liczba & procent \\
\hline talerz & 14 & 26,4 & 170 & 67,7 & 184 & 60,5 \\
\hline talerzyk & 8 & 15,1 & 28 & 11,1 & 36 & 11,9 \\
\hline miseczka & 11 & 20,7 & 3 & 1,2 & 14 & 4,6 \\
\hline misa & - & - & 11 & 4,4 & 11 & 3,6 \\
\hline filiżanka & 10 & 18,9 & 2 & 0,8 & 12 & 4,0 \\
\hline wazon & 1 & 1,9 & 17 & 6,8 & 18 & 5,9 \\
\hline waza & 1 & 1,9 & 7 & 2,8 & 8 & 2,6 \\
\hline dzban & 1 & 1,9 & 7 & 2,8 & 8 & 2,6 \\
\hline imbryk & - & - & 1 & 0,4 & 1 & 0,3 \\
\hline nocnik & - & - & 1 & 0,4 & 1 & 0,3 \\
\hline pokrywka & - & - & 2 & 0,8 & 2 & 0,7 \\
\hline nieokreślony & 7 & 13,2 & 2 & 0,8 & 9 & 3,0 \\
\hline Razem & 53 & 100,0 & 251 & 100,0 & 304 & 100 \\
\hline
\end{tabular}

które stanowi ponad połowę wysokości całego naczynia. Krawędzie kołnierzy są lekko ścięte, sporadycznie zagięte do wewnątrz. Ich średnice w przypadku talerzy fajansowych, mieszczą się w przedziale $16-32 \mathrm{~cm}$, najczęściej wynoszą od 22 do $24 \mathrm{~cm}$. Dna mają średnice od 12 do $14 \mathrm{~cm}$, z reguły są płaskie, bez pierścienia (stopki). Głębokość zrekonstruowanych naczyń wynosi od 2,5 do 5,5 cm. Ścianki mają grubość od 3 do $7 \mathrm{~mm}$. Wymiary talerzy porcelanowych można określić w niewielu przypadkach; ich krawędzie mają średnice $20 \mathrm{~cm}$, zaś dna od 8 do 16 $\mathrm{cm}$, na ogół zaopatrzone są w dookolny pierścień, skośnie ścięty bądź zaokrąglony, o wysokości i szerokości od 3 do $5 \mathrm{~mm}$. Grubość ich ścianek także wynosi 3-5 $\mathrm{mm}$. Część talerzy to egzemplarze niezwykle dekoracyjne, z ornamentami pokrywającymi prawdopodobnie znaczną część powierzchni wewnętrznej. Wśród nich dominują malowane kobaltem wyroby fajansowe, prawdopodobnie pochodzące z warsztatów w Delftach, z okresu od końca XVII do 1. połowy XVIII wieku. Fragment jednego z nich od wewnątrz zdobiony jest niebieskimi motywami roślinnymi, podkreślonymi ciemniejszym konturem, od spodu zaś wiązanymi literami A, P i K, namalowanymi kobaltem (ryc. 6: 7a, 7b). Stanowi on przykład znakowania literowego stosowanego na wyrobach fajansowych produkowanych w Delftach ${ }^{3}$, przypuszczalnie oznaczający A. Pijnacker. Sygnatury takiej używano

${ }^{3}$ System znakowania nie był w Delftach ściśle przestrzegany i miał liczne odstępstwa. Inicjały przybierające formę monogramów lub ligatur można różnie odczytywać, a zestaw tych samych liter mógł oznaczać inne osoby (Piątkiewicz-Dereniowa 1996, s. 11). 
najpewniej pod koniec XVII i w 1. połowie XVIII wieku w warsztacie „De Twee Scheepjes” („Dwie łódeczki”) (Chrościcki 1989, s. 171, nr 2102). Przy założeniu, że są to inicjały imienia i nazwiska właściciela tego warsztatu, byłby to wyrób jednej z bardziej znanych tamtejszych wytwórni z okresu szczytowej produkcji fajansu w tym ośrodku (Chrościcki 1989, s. 160-161).

Dekorację roślinną utrzymaną w niebieskiej kolorystyce ma również fragment sygnowanego talerza porcelanowego (ryc. 7: 1; ryc. 8: 2a, 2b). Znak umieszczony na spodniej części dna jest czytelny i zachowany w całości. Sygnatura, namalowana podszkliwnie kobaltem, ma formę czworobocznego piktogramu; jest to oryginalny znak chiński ${ }^{4}$ stosowany na porcelanie wyrabianej na otwarty rynek, przeznaczonej dla szerokiego odbiorcy. Wyroby takie, charakteryzujące się przeciętną jakością, przez Chińczyków zwane są ,porcelaną z pieców ludowych”. Sygnatura składa się z jednego znaku: 福 - 'fu', czyli ,szczęście”. Prawdopodobnie była ona stosowana przez małe zakłady ,ludowe” od około XIII wieku, a stała się powszechna na przełomie epok Ming i Qing, w XVII wieku5. Na wewnętrznej powierzchni fragmentu naczynia znajduje się precyzyjnie wykonany ornament, zaś zewnętrzną pokrywa szkliwo o jasnobrązowym odcieniu (tzw. brąz kapucyński) ${ }^{6}$. Ułamek pozyskano z warstwy przemieszanej współcześnie, zatem trudno dokładnie określić jego chronologię. Sposób dekoracji i rodzaj szkliwa podobne są na importach z Chin, z okresu od połowy XVI do 1. połowy XVII wieku , a także na wyrobach europejskich wzorowanych na produkcji chińskiej, z około połowy XVIII wieku ${ }^{8}$. Opisywane znalezisko można datować na XVII wiek, zapewne na jego 2. połowę.

$\mathrm{Z}$ kolei na zewnętrznej powierzchni kołnierza innego porcelanowego talerza widnieje znak malowany kobaltem, lecz czytelny tylko częściowo (ryc. 7: 2). Przypomina on ułożone w poziomie widły z kropką (prawdopodobnie podwójne, skrzyżowane ze sobą). Taką sygnaturę (w wersji pojedynczej i podwójnej) stosowano w manufakturze porcelany w Volkstedt w Turyngii od początku jej istnienia w 1762 roku do około końca XIX wieku (Chrościcki 1974, s. 275, nr

\footnotetext{
${ }^{4}$ Najwcześniej znaki malowane stosowali Chińczycy, następnie wytwórnie europejskie, początkowo naśladujące wyroby chińskie. Sygnatury malowane podszkliwnie kobaltem najpierw wykonywano w Miśni w latach 1720-1724 (Chrościcki 1974, s. 9, 245-246, np. nr 1607, 1609, 1611), później także między innymi w Wiedniu w latach 1720-1730 (Chrościcki 1974, s. 133, nr 548) oraz w Worcester w latach 1751-1783 (Chrościcki 1974, s. 107, np. nr 346-352).

5 Według ekspertyzy dr. Marcina Jacoby z Zakładu Sinologii Wydziału Orientalistycznego Uniwersytetu Warszawskiego, któremu składamy serdeczne podziękowanie. Dynastia Ming panowała w Chinach w latach 1368-1644, dynastia Quing w latach 1644-1911.

${ }^{6}$ Niem. Kapuzinerbraun; barwne szkliwo zastosowane na porcelanie europejskiej w Miśni w 1720 roku (Diviš 1984, s. 175).

7 Na przykład naczynia o zbliżonej dekoracji, znalezione podczas badań archeologicznych w Budzie, uznane za wyroby chińskie, datowane na połowę XVI-początek XVII wieku (Holl 2005, s. 139, ryc. 92: 3, 4) lub na 1. połowę XVII wieku (Holl 2005, s. 155, ryc. 106: 4, 5).

${ }^{8} \mathrm{Na}$ przykład podobny wygląd i sposób zdobienia, lecz inne sygnatury, mają znalezione w Warszawie znakowane wyroby manufaktury z Miśni, z lat 1725-1730 (Więcek 2012, s. 99-99; s. 108, tabl. VI: 1, 2) i z około połowy XVIII wieku (Klarecki 2012, s. 110-111, ryc. 1-3).
} 
1827-1830, 1834, 1857-1858). Z uwagi na sposób zdobienia i jakość naczynia można przypuszczać, że pochodzi ono z okresu rozkwitu tej wytwórni ${ }^{9}$ $-\mathrm{z} 2$. połowy XVIII wieku.

Pozostałe talerze $\mathrm{z}$ barwnymi dekoracjami oraz niezdobione to produkty niemieckich, wiedeńskich bądź krajowych wytwórni. Dwa spośród tych ostatnich, fajansowe, także opatrzone są sygnaturami. Na jednym egzemplarzu jest to wytłoczony napis „SUNDERL I” (tj. SUNDERLAND IŁŻA), od nazwiska założyciela wytwórni w Iłży - Lewiego Seliga Sunderlanda. Znaku tego używano w latach 1823-1856 (Chrościcki 1989, s. 35-37). Druga sygnatura przedstawia mitrę i częściowo zachowany napis w ramce: „АБ ЦКОИ” (tzn. ФАБ. ГОРОДНИЦКОЙ - Fab. Gorodnickoj) ${ }^{10}$ (ryc. 5: 5). Takie oznaczenia stosowane były w farfurni w Horodnicy na Wołyniu w latach 1807-1856. Wyroby tej manufaktury były do nabycia między innymi w sklepie fabrycznym, który otwarto w Warszawie w 1830 roku (Chrościcki 1989, s. 34-35).

Mniejsze talerzyki pełniły rolę spodeczków pod filiżanki (np. ryc. 10: 5). Filiżanka i talerzyk (spodek pod nią) stanowiły parę (Wendland 2008, s. 210, przypis 42), natomiast trio składało się z filiżanki do herbaty, kubeczka do kawy i jednego spodka (w angielskim przemyśle ceramicznym; Wedgwood 2002, s. 155). Zakładając zatem, że filiżanki wraz ze spodkami tworzyły komplety, stanowią one łącznie $15,7 \%$ omawianych znalezisk i są drugą (po talerzach) pod względem liczebności grupą naczyń porcelanowych i fajansowych. Część talerzyków ma formę analogiczną do dużych talerzy, większość jednak przypomina małe miseczki - bez wrębu, o lekko rozchylających się ściankach, prostych lub lekko wydętych. Egzemplarze fajansowe mają krawędzie o średnicach od 12 do $18 \mathrm{~cm}$, zaś dna mieszczą się w przedziale od 7 do $11 \mathrm{~cm}$. W dwóch przypadkach określono ich wysokości - wynoszą one $1,5 \mathrm{~cm}$ i $1,8 \mathrm{~cm}$. Wyroby te należą do cienkościennych - ścianki mają od 3 do $5 \mathrm{~mm}$ grubości. Pozostałości wyrobów porcelanowych to głównie fragmenty den o średnicach od 8 do $10 \mathrm{~cm}$. Grubość ich ścianek wynosi od 3 do $4 \mathrm{~mm}$. Dla trzech egzemplarzy znana jest średnica wylewu $-12 \mathrm{~cm}$ (dwukrotnie) i $16 \mathrm{~cm}$ oraz wysokość $-3,0 \mathrm{~cm}, 3,5 \mathrm{~cm}$ i $1,8 \mathrm{~cm}$. Na jednym z porcelanowych spodeczków z około połowy XVIII wieku częściowo zachowała się odciśnięta na spodniej części dna sygnatura przedstawiająca cyfrę „3” (ryc. 1: 10). Zapewne pochodzi on z bliżej nieokreślonej zachodnioeuropejskiej wytwórni ceramicznej.

Filiżanki to naczynia przeznaczone do spożycia herbaty i kawy - napojów, które rozpowszechniały się w Europie w ciągu XVIII wieku (ryc. 8: 3a, 3b; ryc. 9: 1-4; ryc. 10: 3; ryc. 11: 2a, 2b). Początkowo filiżanki produkowane w Europie wzorowano na chińskich - były to czarki bez uch, niskie, rozszerzające się,

\footnotetext{
${ }^{9}$ Szczytowy okres jej produkcji przypadł na lata 1767-1797. Produkowano wówczas serwisy o delikatnych malowanych zdobieniach (Chrościcki 1974, s. 274).

10 Analogiczna sygnatura znajduje się na kubku z Horodnicy na Wołyniu, z lat 1843-1856 (Polski fajans 2004, s. 71-72, nr 50).
} 
o dzwonowatym kształcie. Typy europejskie miały uszko, lekko rozszerzające się bądź cylindryczne ścianki. Te ostatnie, zwane litron, rozpowszechniły się około 1770 roku (Diviš 1984, s. 51; Melegati 1997, s. 106). Egzemplarze znalezione na terenie założenia zamkowego w Tykocinie reprezentują wszystkie trzy wyżej wymienione formy. Najprawdopodobniej naczynia o ściankach prostych (przypominające formą kubeczki) lub tylko lekko rozchylających się, przeważały nad dzwonowatymi. Te ostatnie należy zapewne identyfikować z opisanymi poniżej miseczkami. Filiżanki miały zapewne niewielkie rozmiary oraz cechowały się cienkościennością (ścianki mają grubość od 2 do $3 \mathrm{~mm}$ ). Dominują wśród nich wyroby z porcelany; ich pełna wysokość - z powodu fragmentarycznego stanu zachowania - nie jest znana. Wylewy mierzą od 6 do $9 \mathrm{~cm}$ średnicy, są ustawione prosto lub nieznacznie się rozchylają, ich krawędzie są zaokrąglone lub ścięte. Dna o średnicach od 4,4 do $6 \mathrm{~cm}$ mają niewielki pierścień. Filiżanki fajansowe to tylko dwa egzemplarze; jeden, zrekonstruowany w całości, o cylindrycznym kształcie, z uszkiem ma wylew ze spłaszczoną krawędzią o średnicy $6,2 \mathrm{~cm}$ i płaskie dno ze spłaszczonym pierścieniem o średnicy $6,4 \mathrm{~cm}$, jego wysokość wynosi $6 \mathrm{~cm}$. Ucho w przekroju poprzecznym jest taśmowate, o szerokości $0,9 \mathrm{~cm}$ i długości $6,5 \mathrm{~cm}$. Na dnie filiżanki wytłoczony jest napis „CMIELOW 8”, umożliwiający bezsporną identyfikację miejsca jej produkcji (ryc. 10: 3). Takie sygnatury stosowane były w tej małopolskiej farfurni w latach 1804-1882 (Chrościcki 1989, s. 24-26). Drugi wyrób z fajansu zachowany jest w postaci fragmentu wylewu o średnicy $8 \mathrm{~cm}$. Wprawdzie nie znaleziono innych uchwytów, lecz można sądzić, że występowały one także w pozostałych naczyniach reprezentujących „europejskie” formy. Niemal wszystkie filiżanki (z wyjątkiem jednej fajansowej) to naczynia ozdobne, ich powierzchnie pokrywają ornamenty malowane, głównie o motywach roślinnych bądź w formie poziomych pasków. Większość filiżanek oraz przeznaczonych do nich spodeczków (talerzyków) to przypuszczalnie wyroby pochodzące z wytwórni niemieckich (w tym dwie najprawdopodobniej można uznać za miśnieńskie), angielskich lub wiedeńskich; kilka (a z pewnością egzemplarz sygnowany) to wyroby krajowe. Pochodzą z okresu od około połowy XVIII do 1. połowy XIX wieku.

Miseczki to przede wszystkim naczynia porcelanowe $\mathrm{i}-\mathrm{o}$ ile można to było stwierdzić - niewysokie, w przypadku zrekonstruowanych egzemplarzy mierzące $3 \mathrm{~cm}, 4 \mathrm{~cm}$ lub 4,5 cm wysokości (ryc. 1: 1-3, 5; ryc. 2: 5; ryc. 9: 5, 6, 8). Średnice ich wylewów wynoszą od 8 do $16 \mathrm{~cm}$, a krawędzie z reguły są ścięte od wewnątrz. Dna, o średnicach od 5 do $10 \mathrm{~cm}$, mają niewysokie (od 3 do $4 \mathrm{~mm}$ ) i dość wąskie stopki (od 2 do $4 \mathrm{~mm}$ ). Egzemplarze fajansowe reprezentują dna o średnicach $6 \mathrm{~cm}$ i $8 \mathrm{~cm}$ oraz fragment wylewu o średnicy $12 \mathrm{~cm}$. Wszystkie okazy są cienkościenne (grubości od 2,5 do $4 \mathrm{~mm}$ ). Wyróżniono dwie formy miseczek - o ściankach nieco wydętych (liczniejsze) oraz ustawionych skośnie. Zdecydowana większość to naczynia zdobione, o barwnych dekoracjach, często 

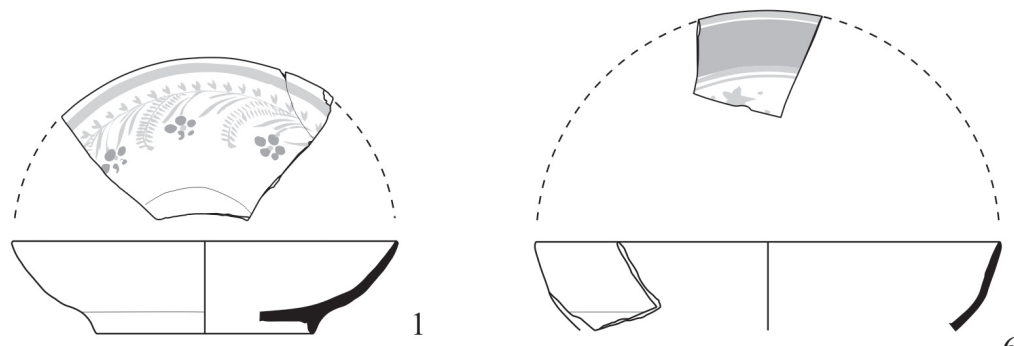

6

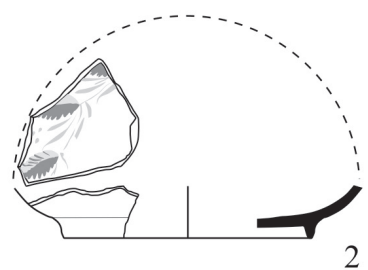

2
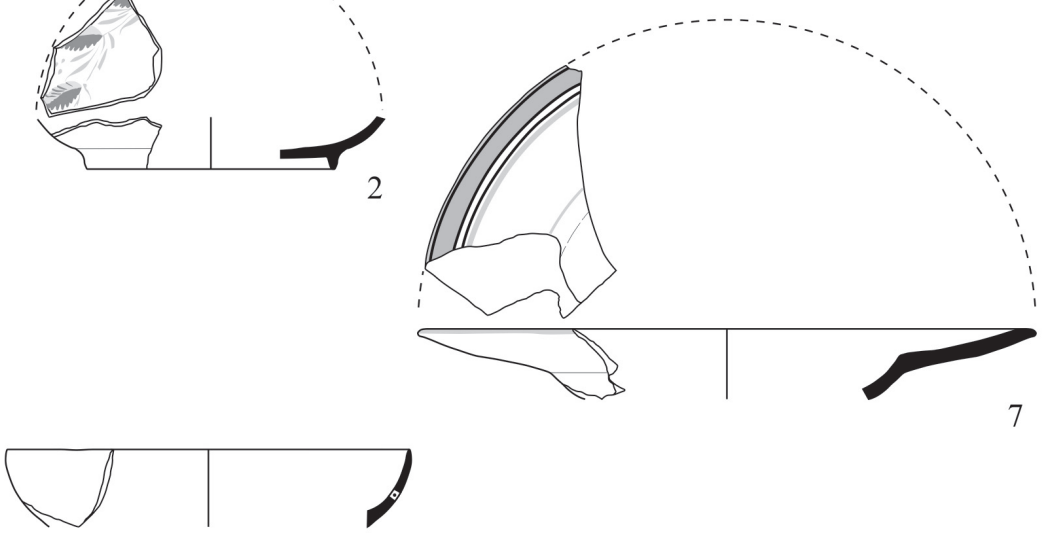

3
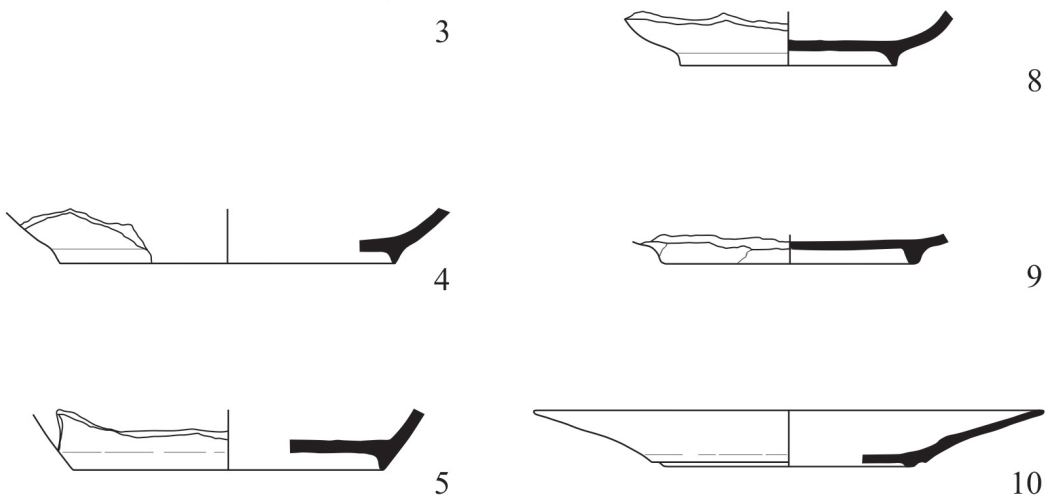

5

Ryc. 1. Tykocin-zamek, woj. podlaskie. Naczynia porcelanowe: 1-5, 8-10-około połowy XVIII wieku; 6, 7- koniec XVIII-początek XIX wieku (rys. M. Bis, M. Wagner)

Fig. 1. Tykocin - castle, Podlaskie province. Porcelain vessels: $1-5,8-10-$ about half of $18^{\text {th }}$ century; 6,7 - end of $18^{\text {th }}$ century-beginning of $19^{\text {th }}$ century (drawing by M. Bis, M. Wagner) 

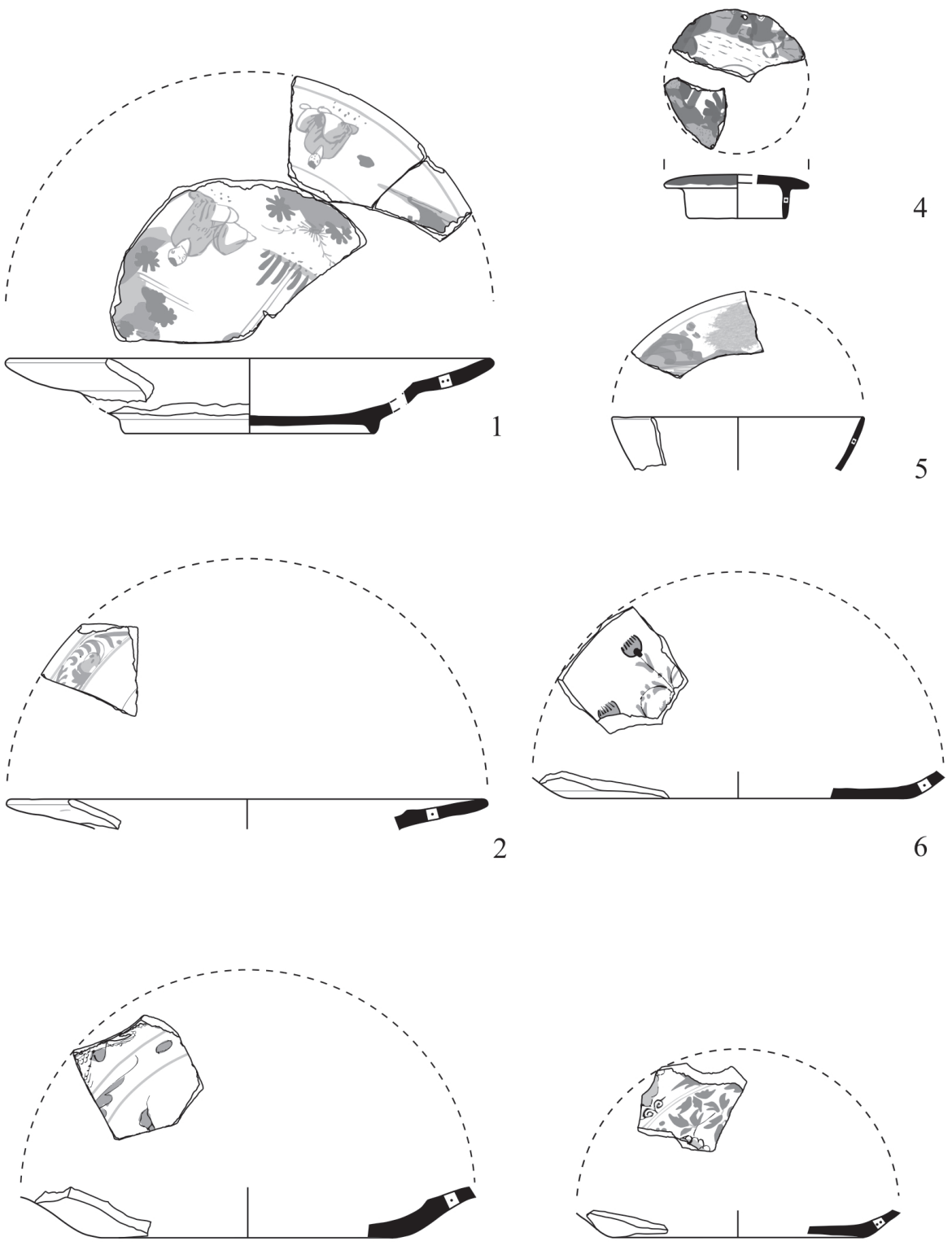

3

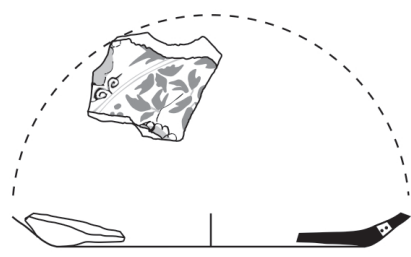

Ryc. 2. Tykocin - zamek, woj. podlaskie. Naczynia fajansowe z końca XVII-1. połowy XVIII wieku (rys. M. Bis, M. Wagner)

Fig. 2. Tykocin - castle, Podlaskie province. Faience vessels from the end of $17^{\text {th }}-1^{\text {st }}$ half of $18^{\text {th }}$ century (drawing by M. Bis, M. Wagner) 

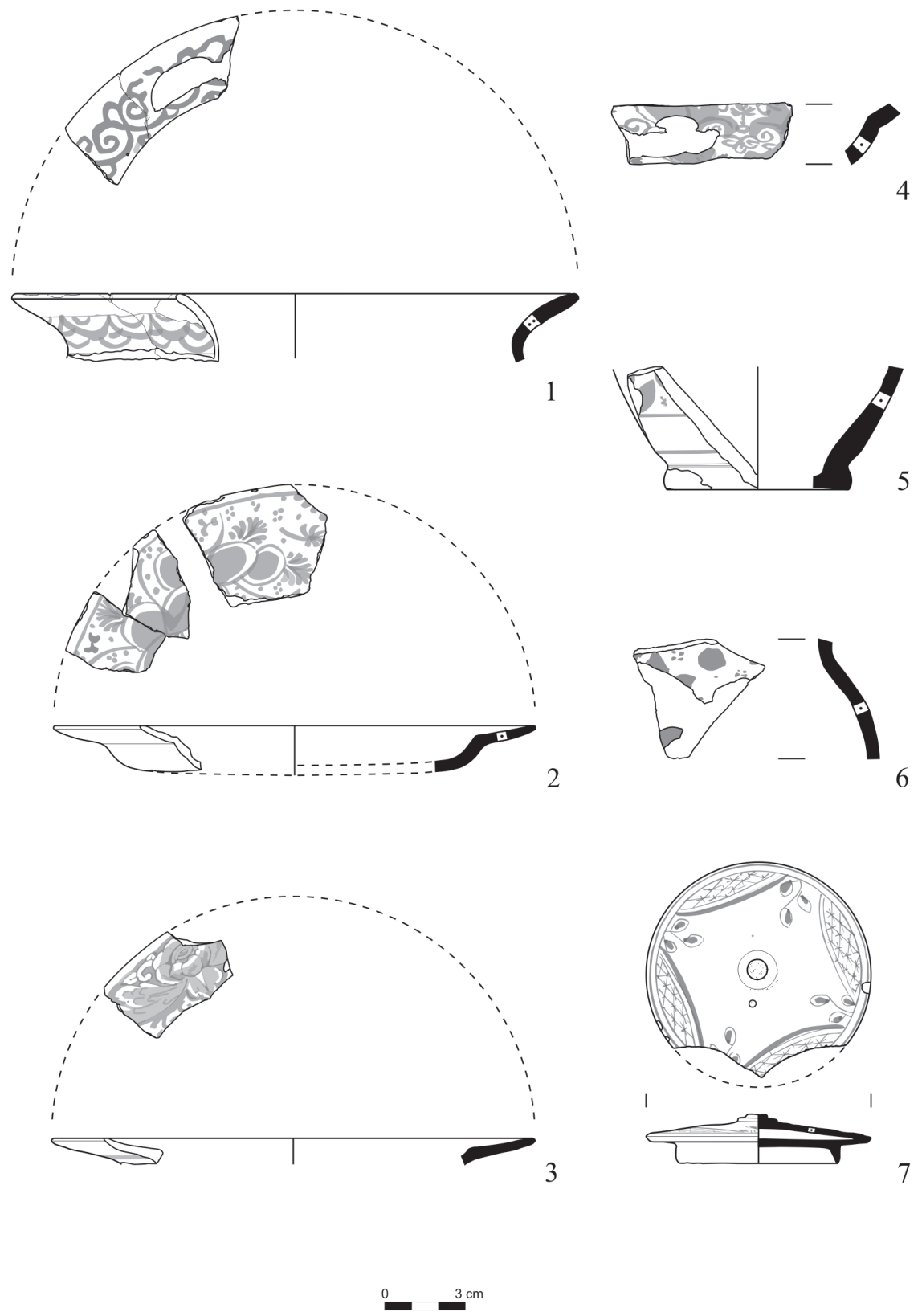

Ryc. 3. Tykocin - zamek, woj. podlaskie. Naczynia fajansowe: 1, 2, 4-6-koniec XVII-1. połowa XVIII wieku; 3, 7 - około połowy XVIII wieku (rys. M. Bis, M. Wagner)

Fig. 3. Tykocin - castle, Podlaskie province. Faience vessels: 1, 2, 4-6-end of $17^{\text {th }}-1^{\text {st }}$ half of $18^{\text {th }}$ century; 3,7 - about half of $18^{\text {th }}$ century (drawing by M. Bis, M. Wagner) 

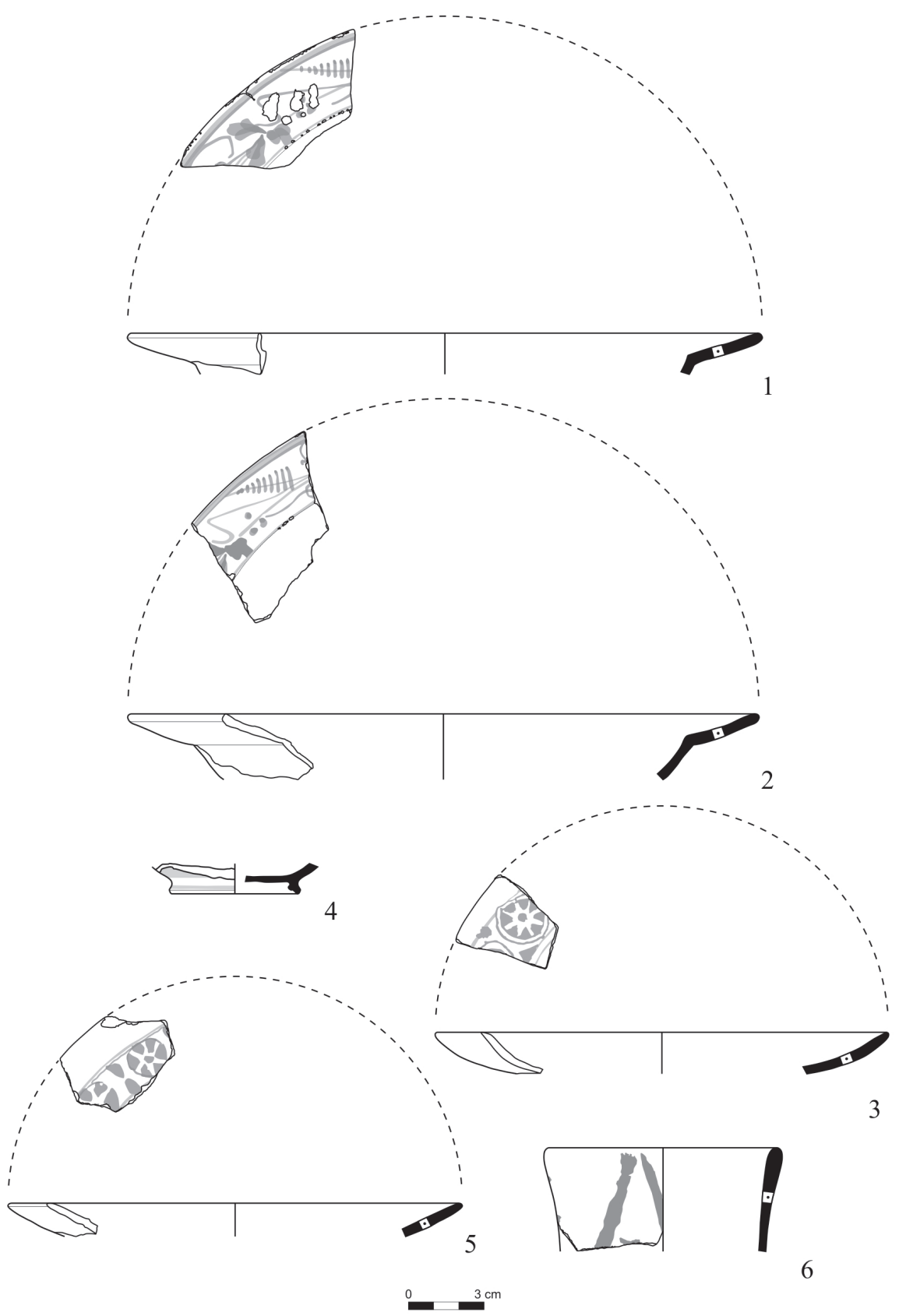

Ryc. 4. Tykocin - zamek, woj. podlaskie. Naczynia fajansowe z 1. połowy XVIII wieku (rys. M. Bis, M. Wagner)

Fig. 4. Tykocin - castle, Podlaskie province. Faience vessels from $1^{\text {st }}$ half of $18^{\text {th }}$ century (drawing by M. Bis, M. Wagner) 

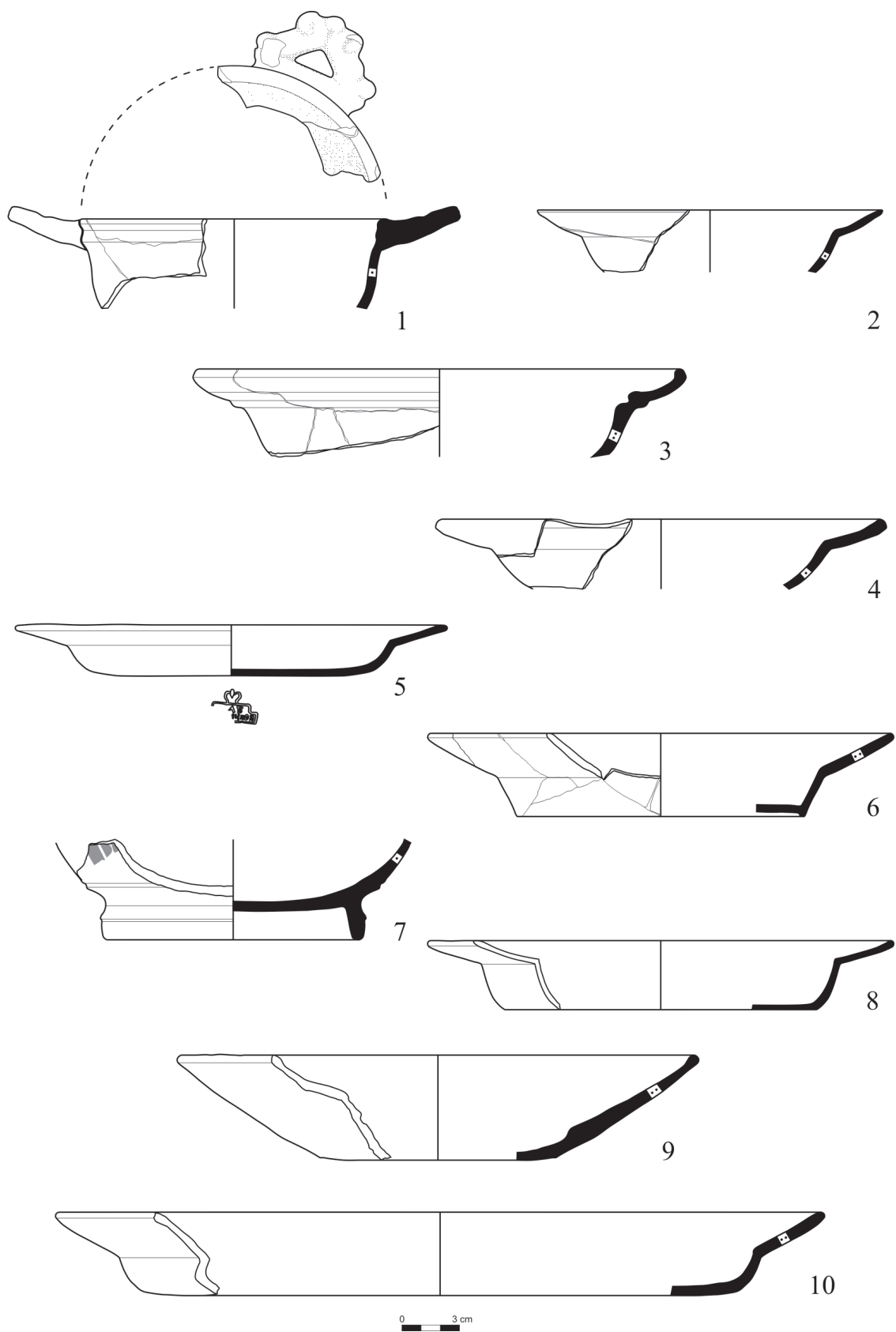

Ryc. 5. Tykocin - zamek, woj. podlaskie. Naczynia fajansowe: 1-4, 6-10-1. połowa XVIII wieku; 5 - 1. połowa XIX wieku (rys. M. Bis, M. Wagner)

Fig. 5. Tykocin - castle, Podlaskie province. Faience vessels: $1-4,6-10-1^{\text {st }}$ half of $18^{\text {th }}$ century; $5-1^{\text {st }}$ half of $19^{\text {th }}$ century (drawing by M. Bis, M. Wagner) 

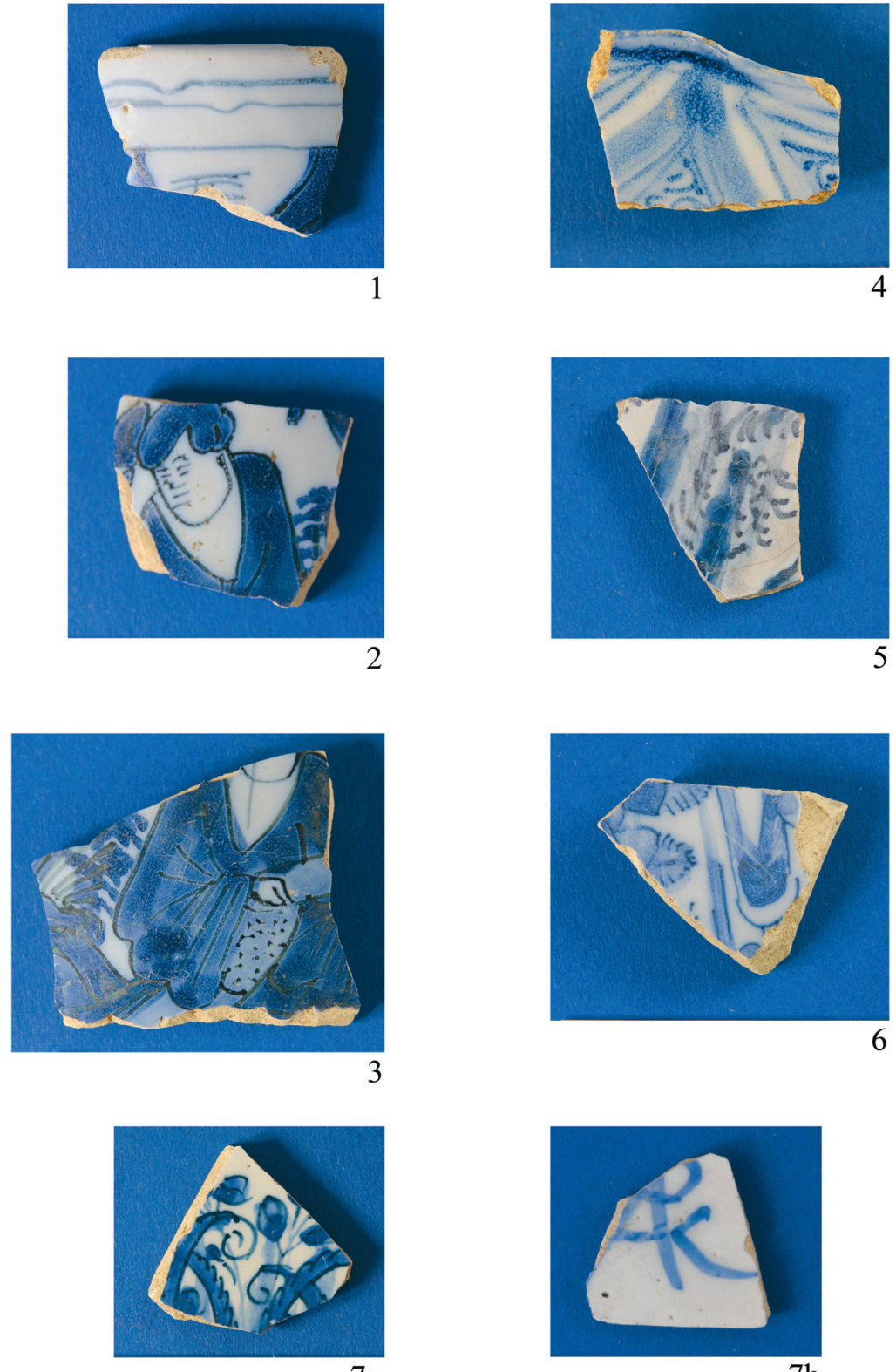

$7 \mathrm{a}$

$7 \mathrm{~b}$

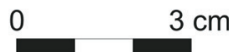

Ryc. 6. Tykocin - zamek, woj. podlaskie. Naczynia fajansowe z końca XVII-1. połowy XVIII wieku (fot. W. Bis)

Fig. 6. Tykocin - castle, Podlaskie province. Faience vessels from the end of $17^{\text {th }}-1^{\text {st }}$ half of $18^{\text {th }}$ century (photo by W. Bis) 

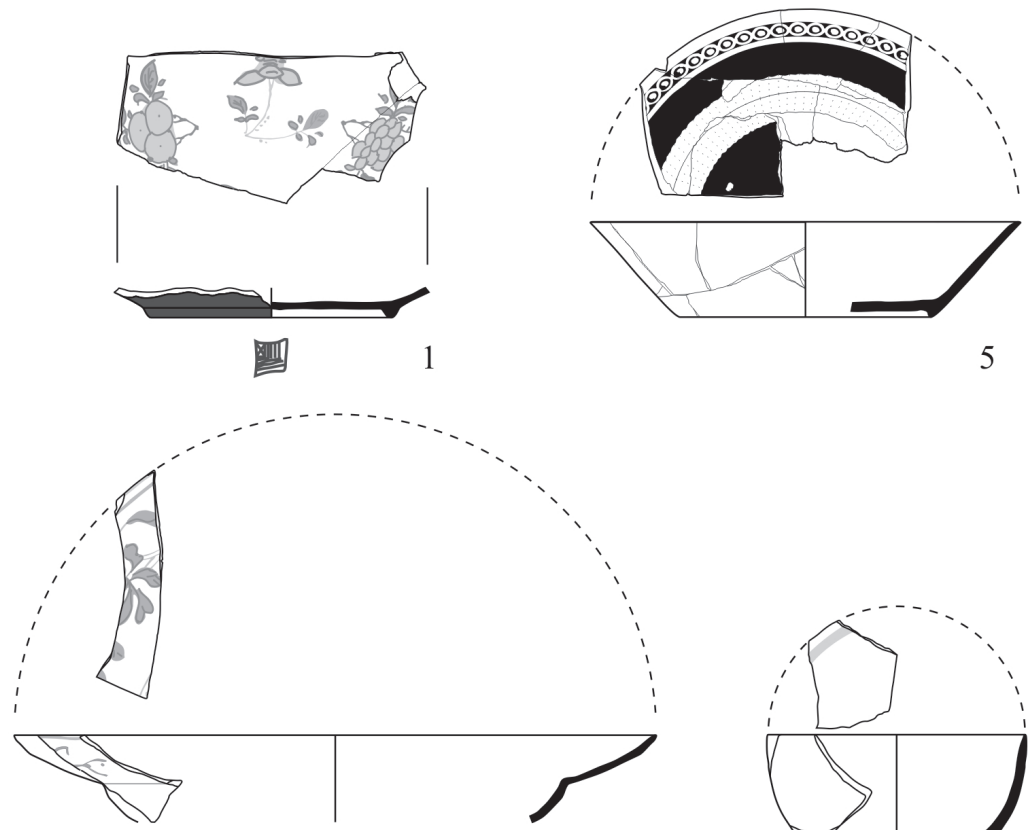

2
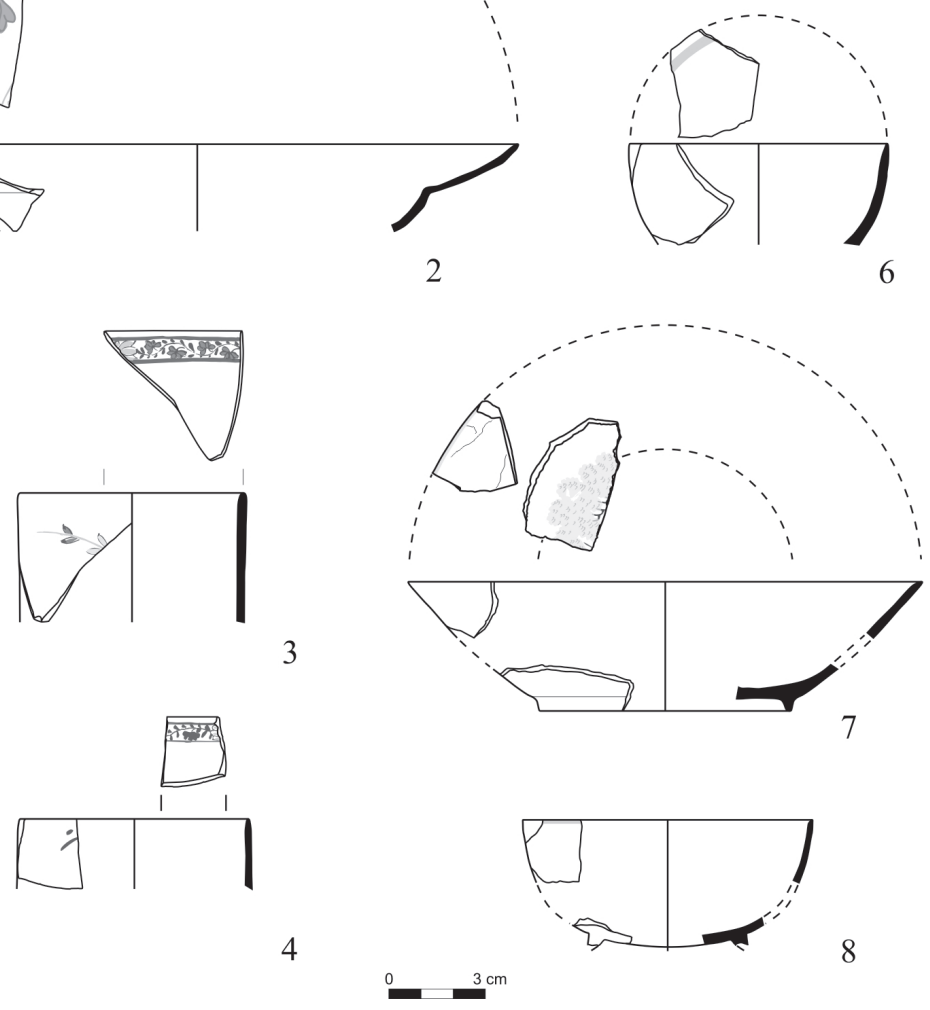

Ryc. 7. Tykocin - zamek, woj. podlaskie. Naczynia porcelanowe: $1-2$. połowa XVII wieku; 3-4-około połowy XVIII wieku; 2, 5-8 - 2. połowa XVIII wieku (rys. M. Bis, M. Wagner)

Fig. 7. Tykocin - castle, Podlaskie province. Porcelain vessels: $1-2^{\text {nd }}$ half of $17^{\text {th }}$ century; $3-4$ - about half of $18^{\text {th }}$ century; $2,5-8-2^{\text {nd }}$ half of $18^{\text {th }}$ century (drawing by M. Bis, M. Wagner) 

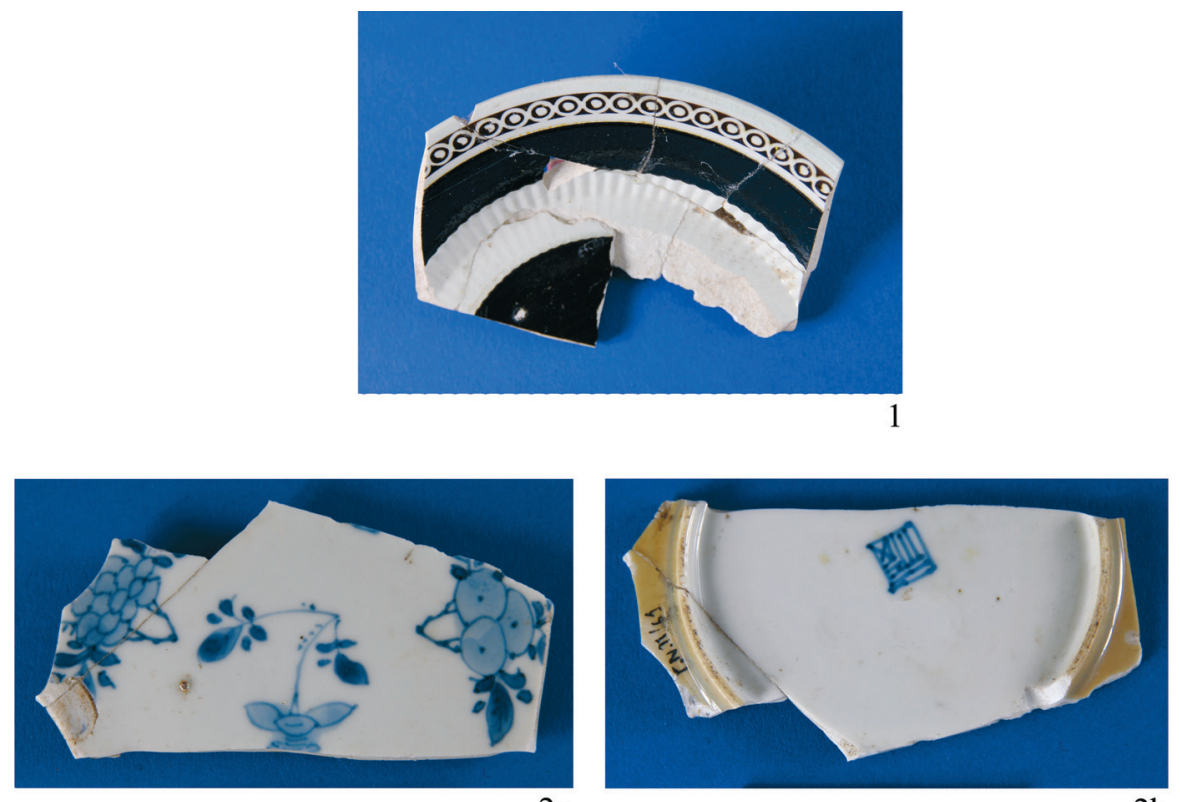

$2 \mathrm{a}$

$2 b$
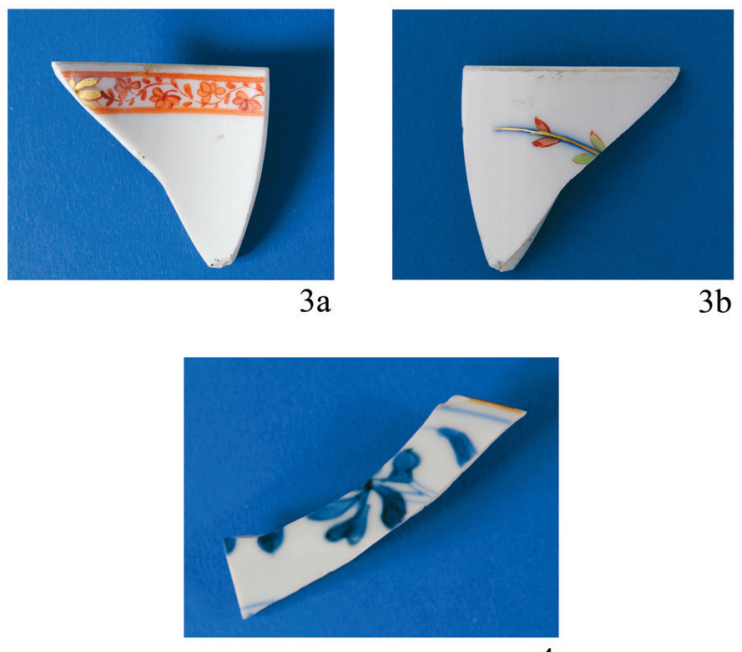

4

0 $3 \mathrm{~cm}$

Ryc. 8. Tykocin-zamek, woj. podlaskie. Naczynia porcelanowe: $2 a, 2 b-2$. połowa XVII wieku; 3a, 3b - około połowy XVIII wieku; 1, 4-2. połowa XVIII wieku (fot. W. Bis)

Fig. 8. Tykocin - castle, Podlaskie province. Porcelain vessels: $2 a, 2 b-2^{\text {nd }}$ half of $17^{\text {th }}$ century; $3 \mathrm{a}, 3 \mathrm{~b}-$ about half of $18^{\text {th }}$ century; $1,4-2^{\text {nd }}$ half of $18^{\text {th }}$ century (photo by W. Bis) 


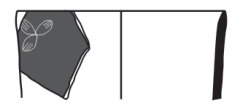

1

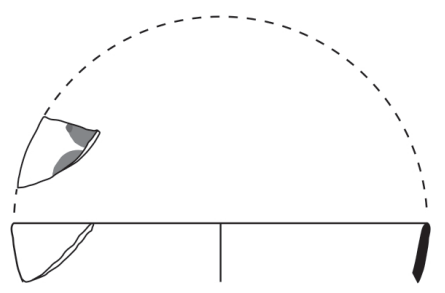

5

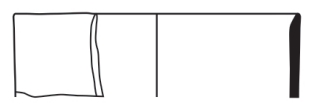

2

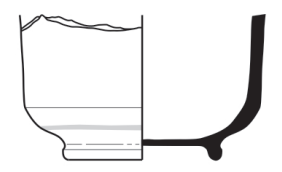

3

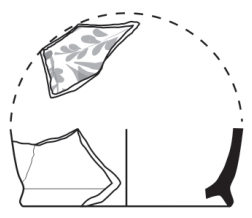

4
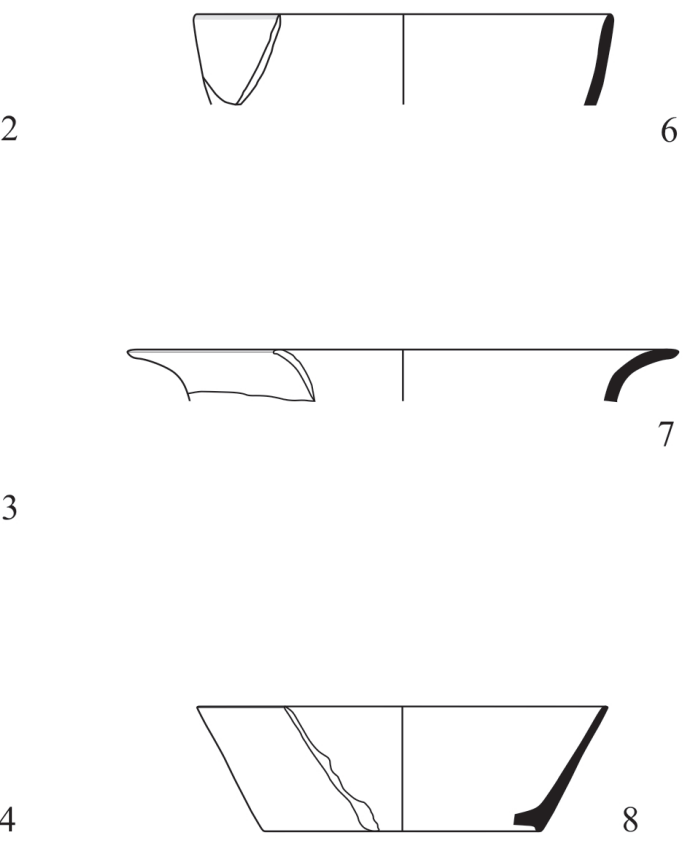

7

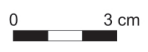

Ryc. 9. Tykocin - zamek, woj. podlaskie. Naczynia porcelanowe: 1-4-około połowy XVIII wieku; 5-8 - koniec XVIII-początek XIX wieku (rys. M. Bis, M. Wagner)

Fig. 9. Tykocin - castle, Podlaskie province. Porcelaine vessels: $1-4-$ about half of $18^{\text {th }}$ century; 5-8 - end of $18^{\text {th }}$ century-beginning of $19^{\text {th }}$ century (drawing by M. Bis, M. Wagner) 

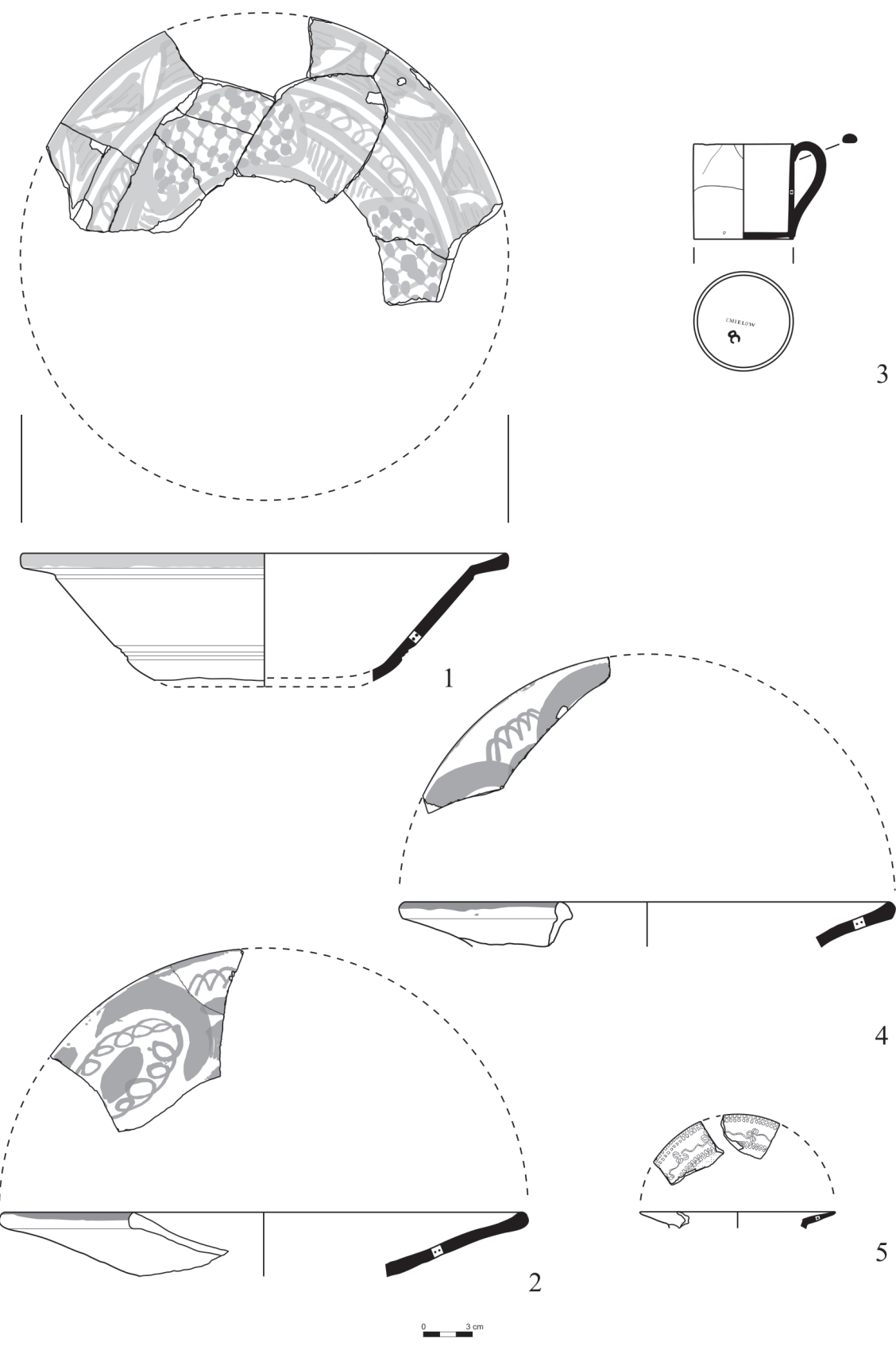

Ryc. 10. Tykocin - zamek, woj. podlaskie. Naczynia fajansowe: 1,2,4-1. połowa XVIII wieku; 3, 5 - 1. połowa XIX wieku (rys. M. Bis, M. Wagner)

Fig. 10. Tykocin - castle, Podlaskie province. Faience vessels: $1,2,4-1^{\text {st }}$ half of $18^{\text {th }}$ century; $3,5-1^{\text {st }}$ half of $19^{\text {th }}$ century (drawing by M. Bis, M. Wagner) 

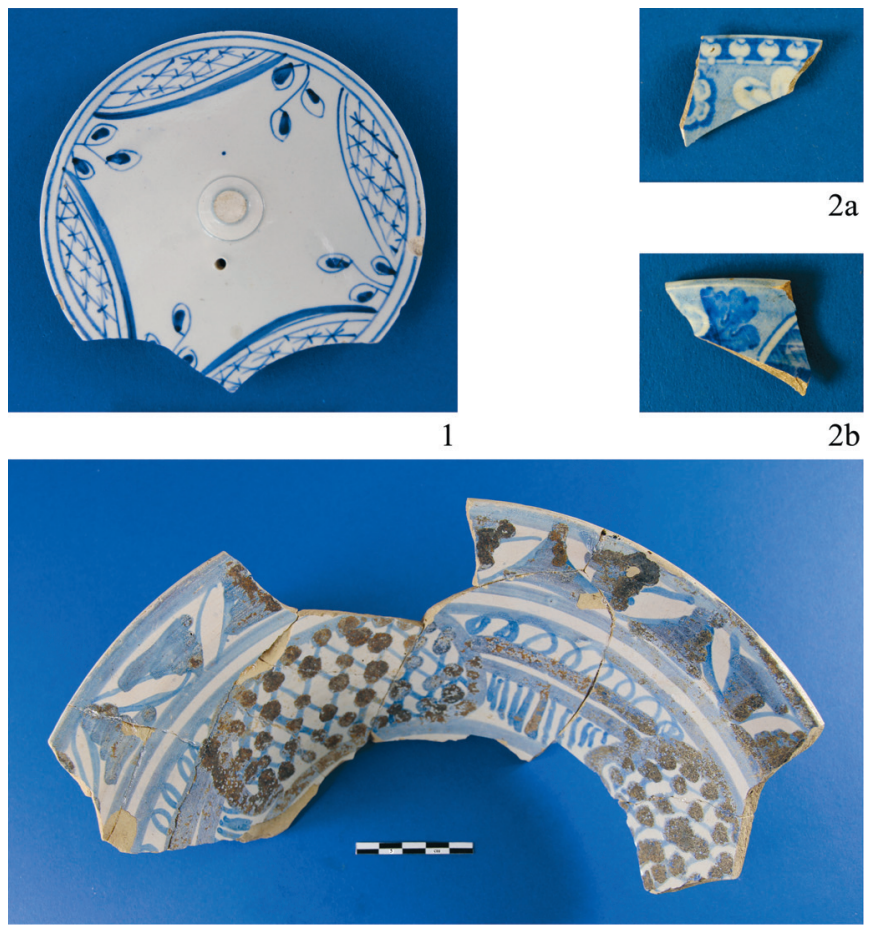

3
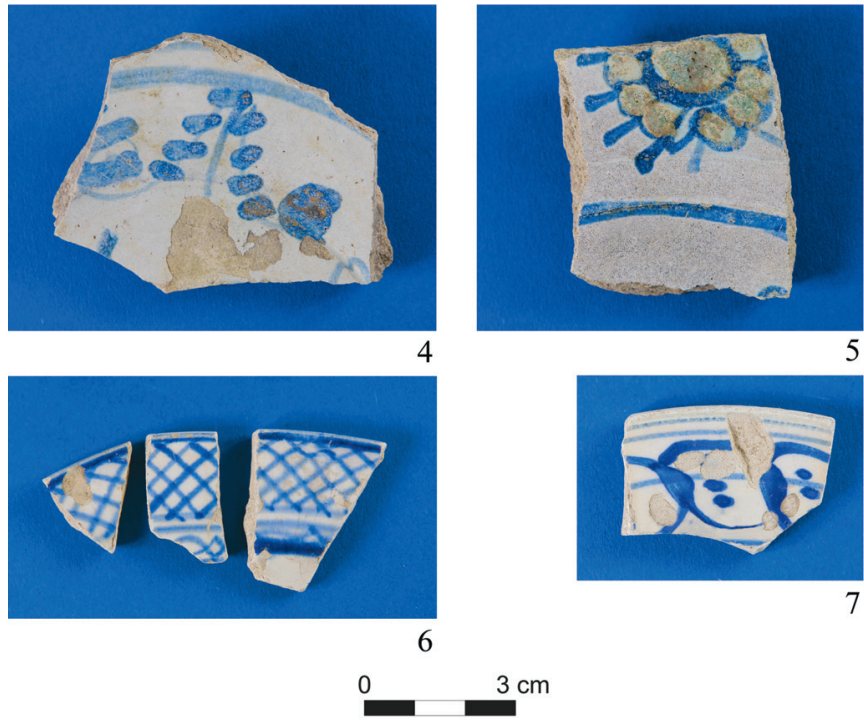

Ryc. 11. Tykocin - zamek, woj. podlaskie. Naczynia fajansowe: 3-7 - 1. połowa XVIII wieku; 1-2a, 2b - około połowy XVIII wieku (fot. W. Bis)

Fig. 11. Tykocin - castle, Podlaskie province. Faience vessels: $3-7-1^{\text {st }}$ half of $18^{\text {th }}$ century; $1-2 \mathrm{a}, 2 \mathrm{~b}-$ about half of $18^{\text {th }}$ century (photo by W. Bis) 
ze złoceniami. Prawdopodobnie pochodzą one z wytwórni niemieckich lub angielskich (około połowy XVIII-1. połowy XIX wieku) oraz - w jednym przypad$\mathrm{ku}-\mathrm{z}$ Delft (koniec XVII-1. połowa XVIII wieku). Na jednym egzemplarzu widnieje niewielka część sygnatury w formie kreski i kropki, malowanej podszkliwnie kobaltem (ryc. 1: 5). Brakuje jednoznacznych podstaw do odtworzenia wyglądu całego znaku, a co za tym idzie do bliższego ustalenia pochodzenia tego wyrobu, zwłaszcza, że wydobyto go z warstwy przemieszanej współcześnie. Można przyjąć, że powstał około połowy XVIII wieku w którejś z zachodnioeuropejskich manufaktur stosujących znakowanie swoich wyrobów w takiej kolorystyce oraz wykonywanych taką techniką.

Misy wchodzące w skład opisywanego zbioru to wyłącznie egzemplarze z fajansu, dużych rozmiarów, lecz prawdopodobnie niezbyt głębokie (ryc. 5: 3; ryc. 10: 1, 2, 4). Najpewniej pełniły funkcje półmisków do podawania różnych produktów żywnościowych. Dwa okazy zrekonstruowano w całości - ich wysokości wynoszą $6,5 \mathrm{~cm}$ i $8 \mathrm{~cm}$, wylewy mają średnice $25 \mathrm{~cm}, 26 \mathrm{~cm}, 28 \mathrm{~cm}, 30 \mathrm{~cm}$ i $43 \mathrm{~cm}$, dna od 14 do $15 \mathrm{~cm}$. Ścianki mis z reguły są dość grube (od 5 do $8 \mathrm{~mm}$ ), rozchylają się znacznie w kierunku wylewu albo są lekko wydęte. Wylewy $z$ reguły są wychylone i wyraźnie oddzielone wrębem od brzuśca, a ich krawędzie są zachylone do wewnątrz. Wśród mis dominują okazy niezdobione, tylko trzy wyroby z tzw. fajansu pomorskiego z 1. połowy XVIII w. mają na wewnętrznej powierzchni malowane ornamenty. Pozostałe egzemplarze zapewne pochodzą z wytwórni zachodnioeuropejskich; ich datowanie zamyka się między 1. połową XVIII a początkiem XIX wieku.

Wśród wazonów również przeważają egzemplarze fajansowe, tylko jeden zrobiony jest z porcelany (ryc. 6: 1-3, 6). Głównie są to niewielkie części brzuśców o różnym stopniu wydętości (w tym także wyrób porcelanowy), lecz analogicznej grubości - od 3 do $5 \mathrm{~mm}$. Z czterech wazonów pozostały fragmenty prostych wylewów o krawędziach zaokrąglonych, pogrubionych lub lekko ściętych i średnicach $9 \mathrm{~cm}, 13 \mathrm{~cm}$ (dwukrotnie) i $16 \mathrm{~cm}$. Większość tych wyrobów (z obu grup gatunkowych) jest dekorowana, przede wszystkim ornamentami malowanymi. Charakter ozdobny ma także puklowana powierzchnia trzech egzemplarzy (w tym jednego porcelanowego). Form wazonów nie udało się zrekonstruować; zapewne były rozmaite (być może charakterystyczne dla wazonów tykwowych lub balastowych), co było przede wszystkim uzależnione od stopnia wydętości brzuśca i umiejscowienia jego największej wypukłości (Piątkiewicz-Dereniowa 1996, s. 139-141). Wśród wazonów fajansowych zdecydowanie dominują wyroby uznane za produkty warsztatów z Delft (12 sztuk), trzy inne to przykłady tzw. fajansu pomorskiego, pozostałe to być może wyroby niemieckie. Brakuje podstaw do ustalenia proweniencji naczynia porcelanowego.

Wazy w XVIII wieku należały do najpowszechniej wyrabianych przedmiotów nie tylko z fajansu i z porcelany, ale także z majoliki; służyły do podawania 
zupy. Miały różne rozmiary, dwa uchwyty i pokrywę (Melegati 1997, s. 120). W opisywanym zbiorze znalazły się fragmenty ośmiu takich naczyń, w tym tylko jednego z porcelany (ryc. 5: 1, 7). Pozostałością egzemplarza porcelanowego jest dno o średnicy $11 \mathrm{~cm}, \mathrm{z}$ wysokim $(9 \mathrm{~mm}$ ) i szerokim (od 4 do $5 \mathrm{~mm}$ ) pierścieniem. Wyraźne stopki mają także fragmenty den waz z fajansu; ich średnice wynoszą $11 \mathrm{~cm}$ i $14 \mathrm{~cm}$. Średnice wylewów egzemplarzy fajansowych to $14 \mathrm{~cm}, 16 \mathrm{~cm}$, 21-22 cm. Wazy zapewne były dość masywne, dlatego też grubość ich ścianek jest nieco większa niż pozostałych rodzajów wyrobów (od 4 do $10 \mathrm{~mm}$ ). Przy wylewie jednej z waz fajansowych zachował się uchwyt o oryginalnej formie i zdobieniu - płaski, o kształcie zbliżonym do trójkąta, z niewielkim otworem, z reliefowym ornamentem na górnej powierzchni (ryc. 5: 1). Na innym widoczne są linie malowane farbą kobaltową. Pozostałe egzemplarze (a przynajmniej analizowane ułamki) nie są dekorowane. Można przypuszczać, że wyroby XVIII-wieczne to importy z wytwórni zachodnioeuropejskich, natomiast XIX-wieczne mogą pochodzić z funkcjonujących już w kraju fajansarni.

Większość dzbanów stanowią wyroby fajansowe (ryc. 4: 6). Z porcelanowego okazu pochodzi tylko fragment niezdobionego, dość masywnego ucha o owalnym przekroju poprzecznym i szerokości $1,8 \mathrm{~cm}$. Zbliżony kształt i rozmiar ( $2,2 \mathrm{~cm}$ szerokości) ma ucho od innego dzbana - fajansowego. Dwa naczynia z tej grupy zachowały się w postaci wylewów - ustawionych prosto, o zaokrąglonych krawędziach i średnicach $9,2 \mathrm{~cm}$ i $11 \mathrm{~cm}$. Pozostałe, najliczniejsze fragmenty egzemplarzy fajansowych, pochodzą z brzuśców. Ścianki wszystkich dzbanów mają $\mathrm{z}$ reguły podobną grubość - od 3 do $5 \mathrm{~mm}$. $Z$ uwagi na rozdrobnienie materiału nie można odtworzyć form naczyń ${ }^{11}$. Większość dzbanów jest ornamentowanych, przypuszczalnie to przede wszystkim wyroby niderlandzkie, a także pomorskie.

Pokrywki to dwa wyroby fajansowe, nieduże, dość płaskie, stożkowate, tzw. „wpuszczane”, zapewne przeznaczone do wazonów lub imbryków (ryc. 2: 4; ryc. 3: 7; ryc. 11: 1). W obu przypadkach nie zachowały się ich uchwyty. Prawdopodobnie wysokość całych okazów wynosiła 3,0-3,5 cm. Różnią się wielkością, głębokością wpustu (piętki) oraz grubością czerepu. Jedna pokrywka jest mniejsza (krawędź o średnicy $7 \mathrm{~cm})$, ma wpust dłuższy $(1,5 \mathrm{~cm})$ i pionowy, jej ścianki są grubsze $(3-4 \mathrm{~mm})$. Druga jest większa (krawędź o średnicy 8,4 cm) i cienkościenna $(2-3 \mathrm{~mm})$, jej wpust jest krótszy $(0,6 \mathrm{~cm})$ i minimalnie rozchylony. Obie mają na zewnętrznej powierzchni zdobienie wykonane farbą kobaltową. Pierwsza pokrywka zapewne pochodzi z Delft, druga prawdopodobnie z Miśni.

Imbryk wykonano z fajansu delikatnego (zwanego creamware), jest pękaty, niewysoki, z jednym uchwytem i długim dziobkiem (ryc. 12: 1a, 1b), najlepiej zachowany w omawianym zbiorze, brakuje tylko przeznaczonej do niego pokrywki. Wysokość naczynia wynosi $11 \mathrm{~cm}$, średnica wylewu $8,5 \mathrm{~cm}$, średnica dna $8 \mathrm{~cm}$,

${ }^{11}$ Dzbany oraz poszczególne ich elementy (m.in. ucha, dziobki, pokrywki) miały rozmaite kształty (Diviš 1984, s. 102, na przykładzie naczyń porcelanowych pochodzących z różnych wytwórni europejskich z XIX wieku). 
maksymalna wydętość brzuśca, przypadająca powyżej połowy wysokości naczynia $-13 \mathrm{~cm}$. Dno jest płaskie i ma niewielką stopkę. Imbryk wyróżnia się delikatnością i dekoracyjnością, jest cienkościenny (ścianki o grubości $2 \mathrm{~mm}$ ). Szczególnie ozdobny charakter ma ucho (o długości $15 \mathrm{~cm}$ ) składające się z dwóch splecionych ze sobą, kanelurowanych taśm (każda o szerokości 1,1 cm). $\mathrm{W}$ miejscu ich mocowania do brzuśca znajdują się nakładki reliefowe $\mathrm{w}$ formie kwiatów i listków. Dziobek ma długość $9,5 \mathrm{~cm}$, jego powierzchnia także jest żłobkowana. Po obu stronach brzuśca znajdują się dwa odmienne motywy zdobnicze w kolorze czarnym, wykonane techniką drukowania. Oba mają charakter symboliczny - jeden przedstawia Minerwę w medalionie wraz z napisem „LET WISDOM UNIT US", drugi zaś leśne gołębie. Na zewnętrznej powierzchni dna znajduje się słabo widoczna, fragmentarycznie odciśnięta litera „W” (być może fragment napisu WEDGWOOD). Wysoka jakość wykonania oraz egzemplarze $\mathrm{z}$ analogicznymi elementami ornamentacyjnymi znane z wytwórni w Staffordshi$\mathrm{re}^{12}$ wskazują na brytyjskie pochodzenie imbryka. Jednakże z uwagi na niewyraźną i przypuszczalnie niekompletną sygnaturę ${ }^{13}$ nie można wykluczyć, że jest to bardzo dobrej jakości krajowa kopia, wykonana według tamtejszych wzorów ${ }^{14}$. Przy założeniu, że jest to oryginalny wyrób angielski, pochodziłby on z 2. połowy XVIII wieku, jeśli zaś byłby imitacją z ziem polskich lub ze Śląska - zapewne z 1. połowy XIX wieku.

W analizowanym zbiorze jeden wyrób fajansowy prawdopodobnie używany był jako naczynie nocne. Takie przeznaczenie sugeruje jego kształt (dość szeroki i rozchylony kołnierz i - o ile to można było stwierdzić - pękaty brzusiec) oraz brak dekoracji. Krawędź kołnierza jest zaokrąglona, jej średnica wynosi $32 \mathrm{~cm}$; ścianki mają grubość $5 \mathrm{~mm}$. Trudne jest ustalenie proweniencji tego wyrobu, przypuszczalnie wykonano go w którejś z krajowych wytwórni na początku XIX wieku.

Wyroby porcelanowe cechują się lepszą jakością niż fajanse, o czym świadczy przede wszystkim stopień spieczenia czerepu, jego grubość i jakość szkliwa. Naczynia porcelanowe wyróżniają się najczęściej białym (85\% tych naczyń), rzadko

${ }^{12}$ Obecnie znajdują się one w brytyjskich kolekcjach antykwarycznych oraz muzealnych, na przykład pojemnik na herbatę i dzbanek do kawy z wytwórni Neal \& Co, datowane około 1780 roku. Za autora tego druku uznaje się Thomasa Rothwell'a.

$13 \mathrm{~W}$ innych europejskich wytwórniach stosowana była także pojedyncza litera „W” odciśnięta w czerepie (Chrościcki 1989, s. 377).

${ }^{14} \mathrm{Na}$ przykład w wytwórni ćmielowskiej w 1. połowie XIX wieku produkowano imitacje angielskich wyrobów fajansowych, na które nanoszono motywy dekoracyjne przy użyciu blach sprowadzonych z zagranicy. Od końca XVIII wieku także w innych manufakturach na ziemiach polskich i na Śląsku wytwarzano ceramikę zwaną „Wedgwoodami”, naśladującą zdobienie i technologię wyrobów angielskich (Wedgwood 2002, s. 65-66). Z uwagi na popularność angielskich fajansów również znaki tamtejszych wytwórni były naśladowane przez manufaktury ceramiczne na kontynencie europejskim, w tym także w Polsce, między innymi w Iłży, Ćmielowie, Włocławku (Chrościcki 1989, s. 12). 
beżowym (15\%) kolorem czerepu, który jest cienki (2-4 mm), z reguły mocno spieczony, a domieszka schudzająca w przełamach nie jest widoczna makroskopowo (dla 77\%). Tylko w niewielu przypadkach (dla $23 \%$ ) odnotowano pojedyncze, drobne ziarna piasku. Powierzchnia niemal wszystkich egzemplarzy $(96 \%)$ jest gładka, a szkliwo jednolite, bez spękań. Wszystkie naczynia porcelanowe pokryte są obustronnie białym szkliwem.

Natomiast czerepy wyrobów fajansowych są bardziej kruche, porowate i grubsze (3-10 mm). Ich zabarwienie najczęściej jest żółtawe (dla 41\% fajansów), beżowe (30\%), rzadziej białe (24\%), sporadycznie jasnopomarańczowe (5\%). We wszystkich przełamach widoczna jest nieplastyczna domieszka piasku o frakcji drobno- lub średnioziarnistej (odpowiednio - 78\% i 22\%), stanowiąca komponent masy ceramicznej. Niekiedy (13\%) warstwa szkliwa, pokrywająca obustronnie te wyroby, ma wadę produkcyjną w postaci drobnej siatki spękań (Rada 1993, s. 69) lub odprysnęła. Cechy te to skutek błędów i usterek technologicznych, świadczących o okresie wytwarzania wyrobów, fachowości obsady, a zwłaszcza o stosowanych surowcach i technologii produkcji (Kowecka, Łosiowie, Winogradow 1983 , s. 127). W niektórych przypadkach (10\% wyrobów fajansowych uznanych za pomorskie lub niemieckie) szkliwiona jest niemal wyłącznie powierzchnia wewnętrzna naczyń, na zewnątrz jedynie krawędź kołnierza. Dominuje szkliwo białe; rzadko jego zabarwienie jest inne - o odcieniu niebieskawym (10-krotnie) lub żółtawym (8-krotnie). Niekiedy wskutek zalegania w ziemi uległo ono zmatowieniu (6\%).

Odsetek naczyń zdobionych w analizowanym zbiorze jest niemały $(44,4 \%)$, przy czym przeważają one wśród wyrobów porcelanowych (57\%), rzadziej występują w grupie okazów fajansowych (42\%). Można założyć, że przynajmniej część niezdobionych, fragmentarycznie zachowanych naczyń także była ornamentowana, lecz w innych, niezachowanych partiach. Z powodu rozdrobnienia materiału dekoracje widoczne są przeważnie w niewielkiej części, dlatego też niejednokrotnie trudno było odtworzyć całe przedstawienie. Sposób ich wykonania jest zróżnicowany - są tu zarówno opracowane z wielkim kunsztem ornamenty na wyrobach z renomowanych wytwórni, jak i bardziej schematyczne, których wykonanie nie wymagało ani szczególnych zdolności plastycznych, ani szczególnej inwencji twórczej. Dominują zdobienia malowane podszkliwnie, rzadziej występują wykonane innymi technikami - malowania naszkliwnego, nakładania gąbką (technika á l'éponge), druku lub wyciskania. Przeważa niebieska kolorystyka. Na wyrobach fajansowych ornamenty są monochromatyczne, ewentualnie zróżnicowane w zakresie odcieni, na przykład błękit i granat, czasem z konturem podkreślonym czarną farbą, zwanym trek (Kilarska 2003, s. 56 i nn.). Malowano je podszkliwnie przy użyciu farby kobaltowej. Zdobienia w kolorze niebieskim lub czarnym wykonywano także techniką druku naszkliwnego. Sporadycznie białe szkliwo stanowi samo w sobie tło dla wzorów reliefowych (wyciskanych 
w czerepie naczyń). Na wyrobach porcelanowych, obok kobaltowych, częściej występują zdobienia wielobarwne z zastosowaniem żółci, brązu, czerwieni, zieleni, czerni i złota, malowane naszkliwnie. Złoceń używano zarówno do wykonania drobnych wzorów (płatków, listków, kropek) bądź uzupełnienia elementów dekoracji wykonanych innymi farbami (przez zastosowanie złotego konturu), ale także w celu podkreślenia formy naczyń (poprzez odpowiednie umiejscowienie pasków). Najczęstszymi motywami dekoracyjnymi zarówno na naczyniach fajansowych, jak i porcelanowych są stylizowane rośliny - głównie pojedyncze kwiaty różnej wielkości (w tym peonie, niezapominajki?, tulipany?), w formie gałązek (wici), także tworzących bordiurę. W analizowanym zbiorze znalazły się także fragmenty przedstawień symbolicznych (Minerwa, gołębie), scen rodzajowych, krajobrazów (ogrody, pole uprawne). Niektórym wyrobom dodają ozdobności faliście profilowane krawędzie (np. gładkim białym talerzom fajansowym) bądź falisty, puklowany brzusiec (naczyniom porcelanowym).

W ornamentyce szczególnie widoczne było naśladownictwo wyrobów orientalnych (chińskich, japońskich i tureckich). Z jednej strony, zwłaszcza w XVII i XVIII wieku, w zachodniej Europie kopiowano oryginalne, wschodnie motywy, usiłując oddać je możliwie jak najdokładniej, z drugiej zaś wprowadzano elementy europejskie. Powstające w ten sposób dekoracje tworzyły nowy styl, będący kompilacją motywów z dwóch odmiennych światów (Kilarska 1981, s. 84; Melegati 1997, s. 65). Wśród omawianych znalezisk przykładami takiego eklektyzmu są błękitne ornamenty kwiatowe na fajansie i porcelanie (ryc. 2: 6; ryc. 7: 2) oraz lambrekiny w tej samej kolorystyce, uzupełniające dekorację powierzchni wazonów fajansowych (ryc. 3: 4). Natomiast znajdujące się w opisywanym zbiorze niderlandzkie wyroby fajansowe z przedstawieniami stojących lub siedzących postaci Chińczyków oraz dalekowschodnich roślin (ryc. 2: 1, 4; ryc. 6: 2, 3, 5, 6) to doskonałe przykłady scen „chińskich” nawiązujących do porcelany „okresu przejściowego" - figuralnych wyobrażeń, których tematy czerpano z chińskich legend, utworów literackich i przypowieści. Charakterystyczne są przede wszystkim sceny spotkań towarzyskich w dalekowschodnich ogrodach; malowano je w najbardziej znanych warsztatach w Delft w 2. połowie XVII i na początku XVIII wieku (Kilarska 2003, s. 59).

Wyroby wiodących europejskich manufaktur ceramicznych były masowo naśladowane. Holenderskie okazy fajansowe $\mathrm{z}$ dekoracją powielającą tę z porcelany orientalnej z czasem same stały się przedmiotem naśladownictw innych wytwórni, na przykład w Rouen, we Frankfurcie nad Menem, w Berlinie (Kilarska 1981, s. 87-88). Do takich elementów ornamentacyjnych zapewne nawiązują bardziej uproszczone i mniej starannie wykonane motywy zdobnicze o niebieskiej kolorystyce, przedstawiające między innymi schematyczne kwiaty (ryc. 4: 1-3, $5,6)$. Występują one na kilku naczyniach przypuszczalnie wyprodukowanych w manufakturach niemieckich. 
Wielobarwne dekoracje, których fragmenty widoczne są na znaleziskach z Tykocina (np. ryc. 13: 1-3, 5), stanowią przykład kolejnego trendu w ornamentyce wyrobów fajansowych i porcelanowych, rozpowszechnionego w 2. połowie XVIII stulecia za pośrednictwem manufaktury miśnieńskiej (Chojnacka 1981a, s. 17; Benini i in. 1998, s. 128-130). Polegał on na zastosowaniu szerszej palety kolorystycznej dzięki opanowaniu umiejętności malowania na wypalonym szkliwie. Znalazło to zastosowanie w wielu wątkach zdobniczych, nie tylko roślinnych (ryc. 1: 1, 2, 6; ryc. 7: 3, 4), ale także w coraz bardziej powszechnych pejzażach, które również występują w analizowanym materiale (ryc. 7: 7, 8). Jednym z ówczesnych osiągnięć w przemyśle ceramicznym było uzyskanie farby o odcieniu różowo-karmazynowym, tzw. purpury, stosowanej zwłaszcza do malowania róż, goździków i tulipanów. Mogły one tworzyć pojedyncze elementy albo wchodziły w skład złożonych motywów, na przykład gałązek, bukietów. Wzorów modnych kompozycji kwiatowych dostarczały wytwórcom różne ówczesne sztychowane wydawnictwa (Chojnacka 1981a, s. 17-18). Być może to płatki któregoś z wymienionych gatunków kwiatów są przedstawione na kilku naczyniach porcelanowych z Tykocina (ryc. 9: 5; ryc. 13: 4).

W 2. połowie XVIII wieku oraz w XIX stuleciu najpierw w Anglii, a potem w całej Europie rozpowszechniły się dekoracje drukowane. Wprowadzenie ich do produkcji ceramicznej miało ogromne znaczenie ekonomiczne ze względu na znaczne obniżenie kosztów (Chrościcki 1989, s. 71), a co za tym idzie na spadek cen wyrobów i ich rozpowszechnienie. Na ziemiach polskich technikę tę w różnych kolorach stosowano na przykład od lat 40. XIX wieku w manufakturze ćmielowskiej ${ }^{15}$ (Chrościcki 1989, s. 25). Przy jej użyciu wykonano motywy zdobnicze na dwóch wyrobach fajansowych z opisywanego zbioru (np. ryc. 12: 1a, 1b).

Pochodzenie $\mathrm{z}$ największym prawdopodobieństwem ustalono $\mathrm{w}$ odniesieniu do okazów sygnowanych, w przypadku analizowanego zbioru było ich $10(3,3 \%)$. Sygnatury równie często mają formę znaków malowanych podszkliwnie kobaltem (głównie wyroby porcelanowe), co wyciskanych w czerepie (głównie wyroby fajansowe). Miejsce produkcji większości pozostałych egzemplarzy określono na podstawie techniki ich wykonania oraz analizy porównawczej. Było to możliwe przede wszystkim dla wyrobów ornamentowanych o elementach zdobniczych charakterystycznych dla określonych warsztatów, ośrodków produkcyjnych lub typów naczyń, znajdujących się głównie w zbiorach polskich muzeów lub wśród opublikowanych znalezisk archeologicznych. Ogólnie jednak ustalanie atrybucji wyrobów fajansowych i porcelanowych nie jest łatwe ze względu na przechodzenie rzemieślników z jednej wytwórni do drugiej, powszechne mody, zbliżony skład masy ceramicznej etc. (Melegati 1997, s. 101). Częstą i powszechną praktyką było powielanie podobnych dekoracji - wzory zapoczątkowane przez

15 Tematyka dekoracji drukowanych w Ćmielowie była wzorowana na popularnych wówczas stalorytach angielskich i niemieckich; były to różnorodne pejzaże sentymentalne, scenki rodzajowe, motywy żołnierskie i myśliwskie (Chrościcki 1989, s. 25; Kluczwajd 2003, s. 40-42). 
jedną manufakturę powtarzane były przez kilka innych (np. Kowecka, Łosiowie, Winogradow 1983, s. 23). Na podstawie sygnatur zidentyfikowano siedem wyrobow (opisanych powyżej): chiński z 2. połowy XVII wieku, prawdopodobnie niderlandzki - z Delft z końca XVII - 1. połowy XVIII wieku, przypuszczalnie angielski - ze Staffordshire z 2. połowy XVIII wieku, niemiecki - z Volksted z 2. połowy XVIII wieku, oraz krajowe - z Iłży, Ćmielowa i Horodnicy z 1. połowy XIX wieku.

Poza tym najliczniej reprezentowane są egzemplarze, które można przypisać warsztatom w Delftach (38 sztuk, 12,5\% wszystkich analizowanych wyrobów, $15 \%$ fajansowych), głównie pochodzące z okresu szczytowej produkcji naczyń fajansowych w tym ośrodku, przypadającej od połowy XVII do połowy XVIII wieku (Chrościcki 1989, s. 160). Cechuje je wysoka jakość wykonania, żółtawy czerep, białe szkliwo tworzące dość grubą warstwę, precyzja wykonania dekoracji malowanych podszkliwnie kobaltem. Wprawdzie ornamenty te zachowały się częściowo, jednak można stwierdzić, że są bardzo podobne do spotykanych na wyrobach fajansowych pochodzących ze wspomnianego ośrodka. Wśród nich zidentyfikowano egzemplarze będące przypuszczalnie dziełem czołowych warsztatów o nazwach „Greckie A” (,De Grieksche A”), „Dwie łodeczki” lub „Dwa Stateczki” („De Twee Sheepjes”), „Paw” („De Paeuw”) lub „Trzy Złocone Beczki Popiołu” („De Drie Vergulde Astonnekens”), należących do znanych właścicieli (odpowiednio): Samuela van Eenhoorna, A. Pijnackera i Gerrita Pietersza Kama (Kilarska 2003, s. 16-17). Naczynia te pochodzą z końca XVII wieku (z ornamentami przypominającymi lambrekiny; np. Piątkiewicz-Dereniowa 1996, s. 44-45, nr 1; s. 46-47, nr 2), z końca XVII-1. połowy XVIII wieku (z motywami nawiązującymi wyraźnie do dalekowschodnich, w tym z postaciami Chińczyków) ${ }^{16}$, z około połowy XVIII wieku (z drobnymi kwiatkami oraz gwiazdkami) ${ }^{17}$

\footnotetext{
${ }^{16}$ Podobne sceny widnieją na rozmaitych naczyniach (dzbanach, kuflach, wazonach, wazach, talerzach, misach balwierskich) pochodzących z końca XVII-1. połowy XVIII wieku, na przykład z warsztatów „De Paeuw” (Piątkiewicz-Dereniowa 1996, s. 96, nr 27; Szarek 2003, s. 111, nr 281), „De Grieksche A” (Kluczwajd 2003, s. 22, nr 29-30), „De Porceleyne Schotel” lub „De Drye Vergulde Astonnekens" (Kluczwajd 2003, s. 23, nr 35), warsztatu Gerrita Pietersza Kama(?) (Balicka-Knotz 2000, s. 16-17, nr 3). Zbliżoną dekorację mają także inne naczynia z tego ośrodka, lecz z nieokreślonych warsztatów (np. Oniszczuk-Rakowska 2002, s. 224; s. 258, pl. XIII:4; Kluczwajd 2003, s. 23, nr 33-34) oraz wyroby manufaktury we Frankfurcie nad Menem (Kluczwajd 2003, s. 29, nr 56; s. 30, nr 57-58).

17 Na przykład występujące na naczyniach (wazonach, talerzach) głównie z końca XVII-początku XVIII wieku z warsztatów „De Porceleyne Schotel” (Kluczwajd 2003, s. 22, nr 31, s. 24, nr 36) i „De Drye Porceleyne Flesschen” (Kluczwajd 2003, s. 24, nr 37-39), z warsztatu Gerrita Pietersza Kama(?) (Balicka-Knotz 2000, s. 12-15, nr 1, 2); oraz z Delft (Birkenmajer 1992, s. 27, naczynie po prawej stronie; Piątkiewicz-Dereniowa 1996, s. 76-77, nr 17; Kwiatkowski 2012, s. 2, fot. 3, 4) Zbliżone motywy zdobią także okazy tzw. fajansu pomorskiego, znalezione w Elblągu, z lat 40. XVIII wieku (Marcinkowski 2011, s. 86-87, nr 42) oraz tzw. Stettiner Ware, znalezione w Stargardzie, z 2. połowy XVIII wieku (Kwiatkowski 2012, okładka).
} 

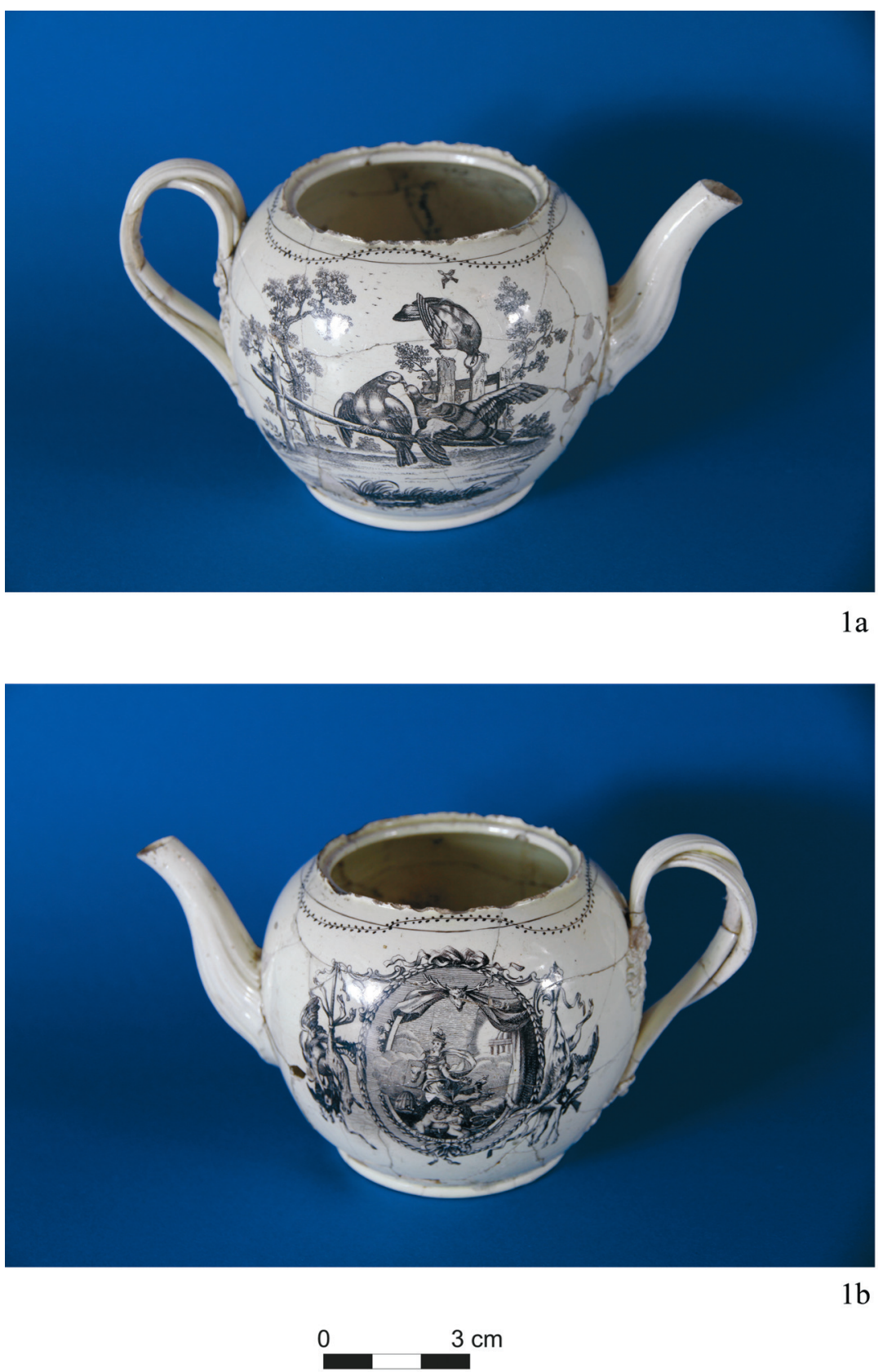

Ryc. 12. Tykocin - zamek, woj. podlaskie. Imbryk fajansowy z 2. połowy XVIII wieku lub 1. połowy XIX wieku (fot. W. Bis)

Fig. 12. Tykocin - castle, Podlaskie province. Faience pot from $2^{\text {nd }}$ half of $18^{\text {th }}$ century or $1^{\text {st }}$ half of $19^{\text {th }}$ century (photo by W. Bis) 

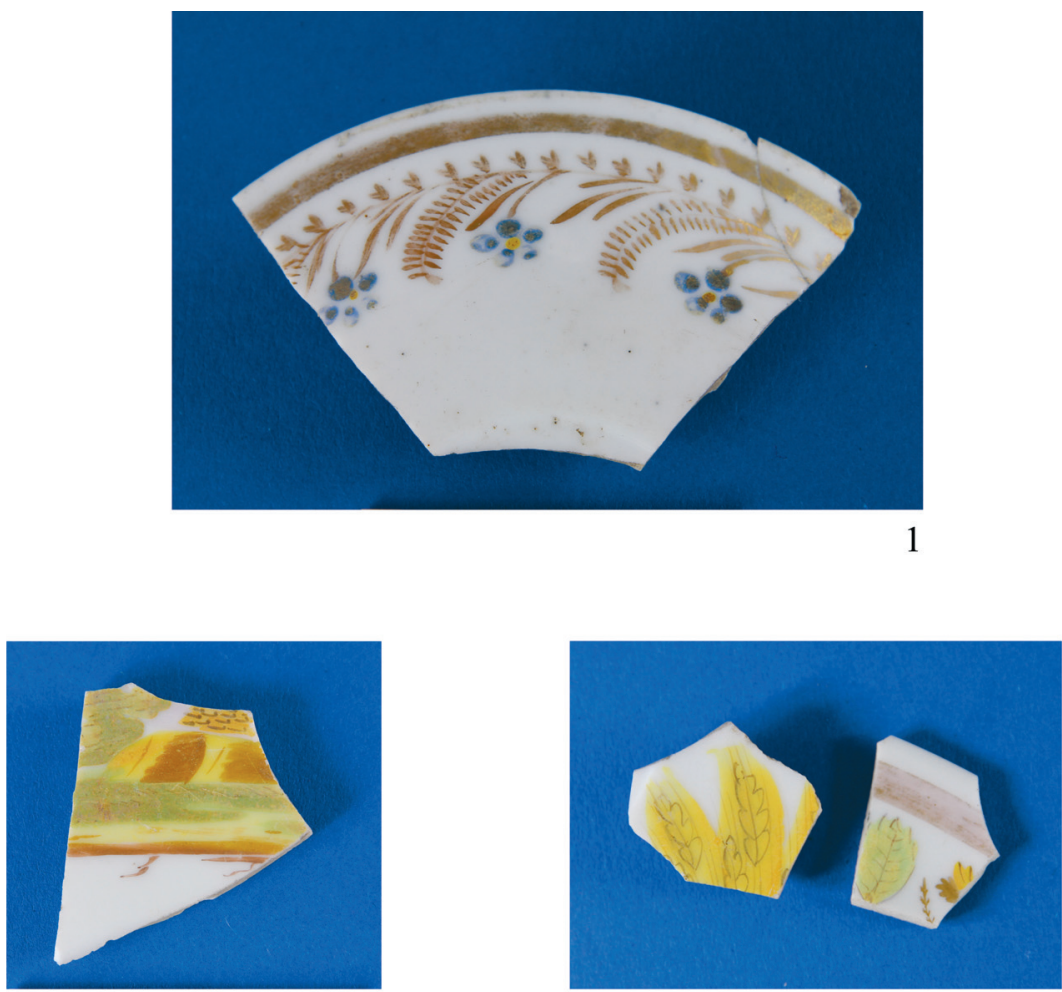

2

3
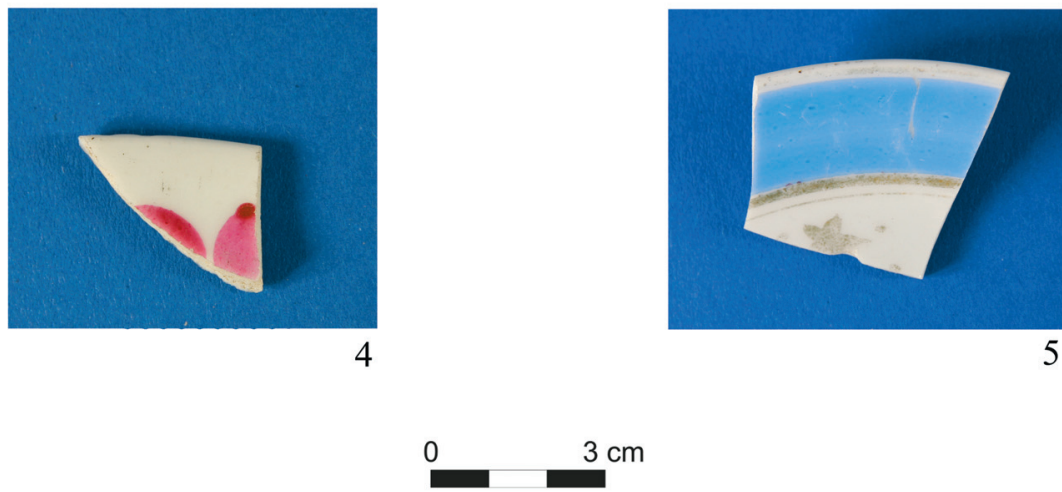

Ryc. 13. Tykocin - zamek, woj. podlaskie. Naczynia porcelanowe: 1 - około połowy XVIII wieku; 2-3-2. połowa XVIII wieku; 4-5-koniec XVIII-początek XIX wieku (fot. W. Bis)

Fig. 13. Tykocin - castle, Podlaskie province. Porcelain vessels: 1 -about half of $18^{\text {th }}$ century; $2-3-2^{\text {nd }}$ half of $18^{\text {th }}$ century; 4-5 - end of $18^{\text {th }}$ century-beginning of $19^{\text {th }}$ century (photo by W. Bis) 
oraz z początku i z 1. połowy XVIII wieku (z wykonanymi gąbką być może scenami rodzajowymi) ${ }^{18}$.

Kolejną pod względem liczebności grupę stanowią naczynia fajansowe o żółtawym lub jasnopomarańczowym zabarwieniu czerepów, szkliwione niemal wyłącznie jednostronnie - na powierzchni wewnętrznej oraz na krawędzi od zewnątrz (24 sztuki, 7,9\% wszystkich analizowanych wyrobów). Do wykonania dekoracji zastosowano głównie farbę niebieską (kobalt), sporadycznie z dodatkiem żółtej i fioletowej; występuje ona w postaci dookolnych linii różnej grubości, dużych kwiatów, kratki (ryc. 10: 1, 2, 4; ryc. 11: 3-5). Naczynia te pochodzą $\mathrm{z}$ warstw datowanych od 2. połowy XVII do około 1. połowy XVIII wieku. Być może są to wyroby tzw. fajansu pomorskiego z wytwórni zlokalizowanych na Pomorzu Gdańskim lub Zachodnim, na przykład w Gdańsku (Marcinkowski 2011, s. 21-25) lub w okolicach Szczecina (te ostatnie to tzw. Stettiner Ware; np. Karwowska 2010, s. 17-20), bowiem najbardziej odpowiadają jakością i stylistyką dekoracji wyrobom przypisywanym tym ośrodkom ${ }^{19}$. Przypominają także produkty z położonego w Turyngii Arnstadt ${ }^{20}$.

Niewiele jest wyrobów z innych ośrodków produkcyjnych, których bliższa identyfikacja byłaby możliwa, ich liczba z reguły nie przekracza kilku sztuk.

Prawie jedną czwartą spośród nich (siedem sztuk wyrobów fajansowych) pozyskano z warstw kulturowych datowanych na 2. połowę XVI wieku. Okazy te są najstarsze w analizowanym zbiorze, bardzo drobne, cienkościenne, o beżowym czerepie, białym, gładkim szkliwie, lekko zabarwionym na niebiesko oraz kobaltowej dekoracji. Być może pochodzą z włoskich wytwórni naśladujących kolorystyką oraz motywami chińskie pierwowzory. Mogą to być również wykonane gdzie indziej - na przykład w funkcjonujących wówczas ośrodkach francuskich - naśladownictwa wyrobów włoskich (Melegati 1997, s. 48-53).

Trzy inne wyroby fajansowe $\mathrm{z}$ dużym prawdopodobieństwem można uznać za produkty farfurni ćmielowskiej, pochodzące z 1. połowy XIX wieku. Charakteryzują się dobrą jakością, cienkościennością, mają białe czerepy i szkliwienie na obu powierzchniach, zdobione są dwoma rodzajami dekoracji - wypukłą, reliefową, w formie subtelnego ornamentu roślinnego (ryc. 10: 5) oraz geometryczno-roślinną w kolorze czarnym, wykonaną techniką barwnego druku. W polskich kolekcjach muzealnych znajdują się okazy z Ćmielowa z lat około 1840-1850 i 1850-1870,

${ }_{18} \mathrm{Na}$ przykład na talerzach z Delft, z okresu od około 1700 roku do pierwszej połowy XVIII wieku (Piątkiewicz-Dereniowa 1996, s. 64-65, nr 11, s. 66-67, nr 12, s. 98-99, nr 28).

19 Na przykład wyrobom znalezionym w Elblągu, pochodzącym z 1. połowy XVIII wieku lub z około 1750 roku (Marcinkowski 2011, s. 50-51, nr 24, s. 58-59, ryc. 13, 14, s. 164-165, nr 81, s. 252-253, nr 125, s. 272-273, nr 135, s. 276-277, nr 137, s. 392-393, nr 195, s. 514-515, nr 256, s. 108-109, nr 53, s. 132-133, nr 65) oraz w Stargardzie Szczecińskim - z 1. połowy XVIII wieku (Kwiatkowski 2012, s. 12, fot. 19).

${ }^{20} \mathrm{Na}$ przykład naczynia apteczne z Arnstadt, datowane na XVII-1. połowę XVIII wieku, znalezione w Hamburgu (Först 2006, s. 69-71, ryc. 32, 33). 
o krawędziach dekorowanych podobnie do tych ostatnich (Starzewska, Jeżewska 1978, ryc. 53, 54; Kluczwajd 2003, s. 41, nr 89-91; Polski fajans 2004, s. 64-65, nr 37-39, s. 66-67, nr 41-44).

Ponadto odnotowano fragmenty dwóch porcelanowych filiżanek, które najpewniej wyprodukowano w najsłynniejszej europejskiej manufakturze - w Miśni, około połowy XVIII wieku, na co wskazuje charakterystyczny ornament wici roślinnej o intensywnej kolorystyce, znany też z innych egzemplarzy (ryc. 7: 3, 4; ryc. 8: 3a, $3 b)^{21}$. Tykocińskie okazy pochodziłyby zatem ze szczytowego rozkwitu tej wytwórni, przypadającego na okres od 1730 do 1756 roku. Był to czas działalności dwóch wybitnych artystów - malarza Johanna Georga Höroldta i modelarza Christiana Heinricha Kändlera, którzy mieli decydujący wpływ na kierunki rozwoju Miśni przez kilka dziesiątków lat (Rudzki 1981, s. 15-16), a ich wyroby oddziaływały na wytwórczość ceramiczną w całej Europie. W miśnieńskiej wytwórni być może powstała również inna filiżanka porcelanowa (ryc. 9: 1), datowana na około połowę XVIII wieku. Wśród innych tykocińskich znalezisk wyróżnia się odmiennym zabarwieniem powierzchni - czarnym, na którym pierwotnie wykonany był malunek złotem w postaci niewielkiego potrójnego liścia. Przypuszczalnie jest to przykład porcelanowej imitacji wyrobów z tzw. kamionki czerwonej, szkliwionej na czarno, ze złoconymi motywami zdobniczymi (Szelegejd 2007, s. 60-63).

Wytwórnie francuskie w Nevers ${ }^{22}$ lub Rouen to prawdopodobnie miejsce produkcji dwóch innych wyrobów fajansowych, datowanych na koniec XVII-1. połowę XVIII wieku (ryc. 6: 5). Przemawia za tym nie tylko wysoka jakość ich wykonania, ale także specyficzne połączenie kolorystyczne pokrywających je malowanych dekoracji, wykonanych z użyciem błękitu kobaltowego oraz brązu manganowego. Były to - jak można sądzić z zachowanych fragmentów - rośliny, stanowiące elementy scen w stylu chinoiserie, które dominowały w tamtejszej wytwórczości w 2. połowie XVII wieku (Nevers; Birkenmajer 1979, s. 62) i 1. połowie XVIII wieku (Rouen; Melegati 1997, s. 128). Z kolei z Sèvres ${ }^{23}$ prawdopodobnie pochodzą dwa kolejne wyroby fajansowe z końca XVIII-początku XIX wieku; są to talerze wyróżniające się intensywną barwą ornamentów umieszczonych na kołnierzach, występujących w postaci pasów niebieskich (o turkusowym odcieniu) w zestawieniu ze złotymi (ryc. 1: 6, 7; ryc. 13: 5).

Z kolei jedną z porcelanowych miseczek z 2. połowy XVIII wieku być może wyprodukowano w Wiedniu. Naczynie jest cienkościenne, ma biały czerep i wewnętrzną powierzchnię częściowo puklowaną, co nadaje jej ozdobną formę, podkreśloną dodatkowo bielą szkliwa, skontrastowaną z czernią farby pokrywającej

${ }^{21}$ Analogiczne zdobienie ma na przykład filiżanka ze spodkiem z Miśni, z lat 1730-1735 (Rudzki 1981, s. 23, ryc. 9) oraz filiżanka ze spodkiem i przykrywka z Miśni z około 1740 roku (Szarek 2003, s. 24 , nr 28, s. 25, nr 30).

${ }^{22}$ Zbliżone dekoracje ma na przykład wazon z początku XVIII wieku (Melegati 1997, s. 128).

${ }^{23}$ Taki kolor występuje na przykład na naczyniach z tego ośrodka z 1753 i 1755 roku (Melegati 1997, s. 111) oraz z lat 1797-1800 (Szkurłat 2011, s. 234, nr 588). 
dno i ściankę. Biało-czarny jest pas dekoracji wypełniony rzędem kółek, optycznie tworzących motyw plecionki. Wzór ten ${ }^{24}$ oraz doskonałość technologiczna wyrobu mogą przemawiać za wspomnianą wyżej proweniencją (ryc. 8: 1).

Dwa kolejne naczynia porcelanowe z 2. połowy XVIII wieku mogły powstać w którejś z wytwórni angielskich, na przykład w Bristolu ${ }^{25}$ lub w Staffordshire (Josiaha Wedgwooda ${ }^{26}$ ) bądź w Prószkowie Śląskim (ryc. 7: 7, 8) ${ }^{27}$. Zdobią je różnokolorowe, namalowane z wprawą motywy - żółte, zielone, brązowo-fioletowe oraz złote. Na pierwszej miseczce widnieje część korony drzewa, na drugiej zaś kłosy zboża i listki. Być może są to części jakichś krajobrazów lub scen rodzajowych.

Prawdopodobnie siedem kolejnych wyrobów porcelanowych także pochodzi z którejś z manufaktur zachodnioeuropejskich - angielskiej lub niemieckiej, z około połowy XVIII wieku. Łączy je - podobnie jak wyżej wymienione - bardzo dobra jakość wykonania, czerepy o białym zabarwieniu, a zwłaszcza precyzyjnie malowane naszkliwnie motywy zdobnicze, głównie listki i drobne kwiatki, wykonane przy użyciu szerszej palety kolorystycznej, w tym złoceń, obecnie miejscami częściowo startych (ryc. 1: 1, 2; ryc. 9: 4; ryc. 13: 1).

Cechą wspólną dwóch innych miseczek z porcelany są podobne fragmenty płatków kwiatów (być może tulipanów lub polnych róż) w odcieniu czerwono-różowym, namalowane na białym tle powierzchni wewnętrznej. $Z$ powodu fragmentarycznie zachowanego materiału brakuje przesłanek do ustalenia czy stanowiły one pojedynczy motyw, czy wchodziły w skład jakiejś kompozycji. Pierwsze z tych naczyń jest starsze - pochodzi z 2. połowy XVIII wieku, zapewne z bliżej nieokreślonej wytwórni zachodnioeuropejskiej. Takie dekoracje były wówczas powszechne, stosowano je w wielu manufakturach. Drugi egzemplarz jest nieco młodszy - z końca XVIII- początku XIX wieku i przypuszczalnie stanowi wytwór farfurni wołyńskich - Korca lub Baranówki ${ }^{28}$ (ryc. 9: 5; ryc. 13: 4). Między innymi w tamtejszych manufakturach powstawały w tym czasie naczynia zdobione wielobarwnymi motywami kwiatowymi (np. Chrościcki 1974, s. 24, 38) ${ }^{29}$.

${ }^{24}$ Zbliżony wzór plecionki, lecz w innej kolorystyce (zielono-biały), występuje na porcelanie z manufaktury wiedeńskiej, wchodzącej w skład serwisu dworskiego z 1780 roku (Benini i in. 1998, s. 133). Wcześniej, w 1. połowie XVIII wieku, w wytwórni tej produkowano naczynia, których brzegi zdobiono między innymi monochromatycznymi, czarnymi dekoracjami (Benini i in. 1998, s. 138).

25 Dość podobnie malowane drzewo widnieje na sześciobocznym wazonie z dekoracją pejzażową, pochodzącym z Bristolu, datowanym na około 1775 rok (Melegati 1997, s. 121).

${ }^{26}$ Na przykład filiżanki ze spodkami z około 1815 roku (Wedgwood 2002, s. 155, nr 195).

${ }^{27} \mathrm{Na}$ przykład podobne ornamenty na naczyniach z Prószkowa Śląskiego, z lat 1770-1783 (Starzewska, Jeżewska 1978, ryc. 16; Polski fajans 2004, s. 44-45, nr 12, 15).

28 Wytwórnia w Korcu działała od 1783 do 1832 roku, przy czym produkcję porcelany rozpoczęto tam w 1790 roku (Chrościcki 1974, s. 23), zaś w Baranówce - od 1804 roku do początku XX wieku (Chrościcki 1974, s. 36).

29 Podobne kwiatowe ornamenty widnieją na przykład na naczyniach z Korca, pochodzących z okresu od 1790 do 1832 roku (Chojnacka 1981b, s. 7-9, ryc. 1-3, s. $12-13$, ryc. 6, 7; s. 24, ryc. 15 , s. 26, ryc. 17; Kowecka, Łosiowie, Winogradow 1983, ryc. 17-20, 23, 78, 79, 84, 85) oraz 
Pozostałe, niezdobione wyroby fajansowe i porcelanowe znalezione na zamku w Tykocinie, pochodzące z 2. połowy XVIII oraz z XIX wieku (łącznie 206 sztuk, $67,8 \%$ wszystkich analizowanych wyrobów), to przede wszystkim egzemplarze o walorach użytkowych (większość z nich to talerze). Stanowią one albo importy z zachodniej Europy, albo pochodzą z wytwórni śląskich lub polskich.

Pod względem rodzajów i ornamentyki opisywane naczynia odpowiadają powszechnym trendom w zachodnioeuropejskiej i krajowej wytwórczości ceramicznej zwłaszcza od schyłku XVII po XIX wiek. Zarejestrowany asortyment to najpowszechniejsze formy używane w tym czasie - elementy serwisów obiadowych lub kawowych, pojemniki na kwiaty. W skład tego zestawu wchodzą między innymi najkosztowniejsze i najbardziej pożądane wówczas holenderskie wyroby fajansowe z Delft, angielskie naczynia z manufaktury J. Wedgwooda(?) oraz wyroby porcelanowe z położonej w Saksonii Miśni czy z królewskiej manufaktury wiedeńskiej (Wendland 2008, s. 207, przypis 34). Początkowo nabywali je przedstawiciele magnaterii, majętna szlachta, przede wszystkim osoby otwarte na świat, chętnie adoptujące nowe mody. Dopiero z czasem - w 2. połowie XVIII wieku - naczynia te rozpowszechniły się w Polsce w innych środowiskach, szczególnie mieszczańskich i szlacheckich (Wendland 2008, s. 217-234).

$*$

Opisane znaleziska w zdecydowanej większości pochodzą z warstw kulturowych odnoszących się do dwóch poziomów chronologicznych wyróżnionych na terenie tykocińskiego założenia zamkowego. Pierwszy przypada na okres od 1661 do około 1769 roku. Murowany zamek o renesansowej metryce, stanowiący element twierdzy ${ }^{30}$, wraz z okolicznymi dobrami został nadany przez sejm Stefanowi Czarnieckiemu. Podczas potopu, zwłaszcza szturmu w roku 1657, obiekt uległ znacznemu zniszczeniu, lecz - jak można wnosić ze źródeł pisanych - funkcjonował jeszcze (przynajmniej jego skrzydła zachodnie i południowe) około stulecia. Po śmierci hetmana, w 1665 roku, przez jego córkę majętności te znalazły się w posiadaniu rodziny Branickich, herbu Gryf. Mąż Aleksandry Katarzyny Czarnieckiej - Jan Klemens II (lata około 1624-1673), podniósł rangę rodu, budując swą karierę przy pomocy dworu królewskiego oraz zdobywając liczne nadania królewszczyzn. Ostatecznie znalazł się w czołówce ich posiadaczy i osiągnął magnacką fortunę. Królewszczyzny i jego własne posiadłości koncentrowały się w trzech ośrodkach, przy czym dobra tykocińskie wchodziły w skład najważniejszego klucza podlaskiego (Zielińska 1997, s. 35). Kolejnym męskim przedstawicielem rodu i właścicielem Tykocina był Stefan Mikołaj (zmarły w 1709 roku). Działalność publiczną rozpoczął

z Baranówki z lat 1825-1840 (Chojnacka 1981b, s. 29, ryc. 20; Kowecka, Łosiowie, Winogradow 1983 , ryc. 92, ryc. 123).

30 Twierdza zapewne została wzniesiona w czasie panowania Zygmunta III Wazy, gdy funkcję starosty tykocińskiego pełnił Krzysztof Wiesiołowski (w latach 1617-1637). 
po śmierci ojca, za panowania Jana III Sobieskiego, lecz nie odegrał w tym zakresie jakiejś znaczącej roli; otrzymawszy jedynie tytuł stolnika koronnego (1688 rok). Poprzez małżeństwo z Katarzyną Scholastyką Sapieżanką (w 1686 roku) związał się politycznie z obozem Sapiehów. Utrzymał odziedziczone włości, a rodowy majątek powiększył jeszcze o kolejne dobra na Podlasiu - Sobolewo i Dojlidy, będące zastawem od Radziwiłłów; nabył też dobra choroskie (Zielińska 1997, s. 35-37).

Zapewne z inicjatywy Jana Klemensa II oraz Stefana Mikołaja podjęto działania zmierzające do remontu i modernizacji wnętrz zamkowych w Tykocinie w 2. połowie XVII stulecia. Prace te polegały między innymi na wymianie oszklenia okien, stawianiu nowych pieców grzewczych etc. Zamek prawdopodobnie przez obu właścicieli uważany był za jedną z ważniejszych siedzib rodowych, gdzie często i długo przebywali zanim przenieśli się do Białegostoku (Baranowski 1991, s. 67). Jak można przypuszczać, względy prestiżowe obiektu (jego wielkość i znaczenie) mogły odgrywać niebagatelną rolę dla bogacących się i chcących wzmocnić swoją pozycję Branickich, mimo że utrzymanie tak dużego obiektu z pewnością było kosztowne i wymagało stałych nakładów. Z opisów z lat 1698 i 1701 wynika, że ówczesny wygląd i stan zachowania funkcjonującej części zamku nie przedstawiały się najgorzej (Maroszek 2000, s. 331-341).

Do ponownego zniszczenia obiektu przyczyniły się wydarzenia związane z wojną północną. W 1702 roku zamek zajęły wojska szwedzkie, a w następnych latach przez Tykocin przechodziły liczne oddziały polskie, litewskie, saskie i rosyjskie. Zwłaszcza te dwa ostatnie systematycznie plądrowały okoliczne dobra Branickich, ponieważ Stefan Mikołaj był stronnikiem Stanisława Leszczyńskiego. Krótko przebywali tu ze swoimi dworami: August II, car Piotr I i Stanisław Leszczyński (Łopatecki 2009, s. 66, przypis 15). Zamek, tak jak miasto, dotykały również klęski żywiołowe, na przykład w 1714 roku został zalany wodami Narwi. „Pałac staroświecki murowany” (jak określono go w inwentarzu z 1715 roku) nadal jednak utrzymywano, dokonując niezbędnych napraw i remontów (Maroszek 2000, s. 331-341). W 1734 roku zamek został jednak spalony cum mobilius przez zwolenników Stanisława Leszczyńskiego (Choińska 2009/2010, s. 35-36), a poniesione straty oszacowano na 100000 f(florenów?) (Regestr Szkod Uczynionych, CXX/58). Miało to miejsce w czasie, gdy tutejsze dobra należały już do kolejnego z Branickich - Jana Klemensa III (stronnika Wettynów). Odziedziczył on znaczny majątek, który sam jeszcze pomnożył. Sprawował kolejne urzędy wojskowe i cywilne, uwieńczone najważniejszymi - urzędem kasztelana krakowskiego i hetmana wielkiego koronnego (Zielińska 2006, s. 209). Olbrzymia fortuna umożliwiała mu realizację licznych inwestycji budowlanych, świetne wyposażenie wznoszonych lub przebudowywanych siedzib (łącznie posiadał kilkanaście rezydencji, lecz najważniejszymi stały się pałace w Białymstoku i Warszawie) oraz prowadzenie luksusowego trybu życia. Przywiązywał wagę między innymi do drobiazgów tyczących się wygody i stołu (Kowecka 1991, s. 27). 
Dysponując innymi, okazałymi i bardziej odpowiednimi siedzibami, prawdopodobnie pod koniec lat 60. XVIII wieku (najpóźniej w roku 1769), Klemens Branicki zdecydował o rozbiórce obiektu w Tykocinie, z powodu ,zrujnowania [...] trudności go utrzymania i reparacji” (Trzebiński 1955, s. 94). Zakres tych prac nie jest jednak znany. Według wzmianki z roku 1771 ,na tym miejscu rudera tylko i znaki dawnej wspaniałości”, chociaż „niegdyś zamek obronny [tu] bywał” (Trzebiński 1955, s. 94). Uzyskane materiały budowlane zostały przeznaczone do wzniesienia nowego kościoła i klasztoru księży misjonarzy w południowej części Tykocina.

Drugi poziom chronologiczny przypada od około 1769 roku, czyli po rozbiórce murów zamkowych, do 1963 roku, tj do czasu ukończenia budowy trwałej ruiny zamkowej w latach 60. ubiegłego wieku. W tym okresie zamek nie pełnił już swoich zasadniczych funkcji - ani obronnej, ani administracyjnej. Po śmierci Jana Klemensa III (w 1771 roku) Tykocin wraz z założeniem stanowił dożywotnią własność (do 1808 roku) jego ostatniej żony, Izabeli z Poniatowskich. Po niej zaś, drogą spadku przeszedł na Potockich, wreszcie Rostworowskich (Stownik 1892, s. 697). Obiekt stopniowo podupadał już w 2. połowie XVIII wieku, a w latach 60. XIX wieku pozostały po nim ,tylko gruzy i rozwaliny [...] wież, baszt, bram ani śladu" (Encyklopedyja 1867, s. 832). Od 1807 do 1915 roku w pozostałościach zamku mieściła się jeszcze komora celna, nazywana w miejscowej gwarze Tamożnią. Resztki ruin zamkowych wykorzystane zostały jeszcze po 1915 roku jako budulec na drogę prowadzącą do sąsiedniej miejscowości, przebiegającą przez teren twierdzy (Maroszek 2000, s. 331, przypis 61).

Większość opisanych wyrobów fajansowych i porcelanowych było w użyciu, gdy zamek stanowił własność dwóch ostatnich przedstawicieli rodu Branickich. Nie można wykluczyć, że niektóre z nich dotarły tu w początkowych latach XVIII wieku wraz z dworami polskich bądź zagranicznych monarchów (Stownik 1892, s. 697; Łopatecki 2009, s. 66, przypis 15).

Na podstawie istniejących opracowań dysponujemy informacjami jedynie na temat ruchomości należących do Jana Klemensa III (przede wszystkim Kowecka 1991), nie mamy zaś danych odnośnie przedmiotów należących do jego ojca. Można założyć, że majątek, jaki posiadał Stefan Mikołaj umożliwiał mu zakup wyszukanych drobiazgów, w tym wchodzących w skład zastawy stołowej. Osiągnięta przez niego pozycja społeczna wiązała się z koniecznością podążania za nowymi obyczajami, jaką między innymi była konsumpcja kolonialnych używek przy użyciu przeznaczonych do tego celu odpowiednich utensyliów.

W publikacjach, brakuje bezpośrednich wzmianek o przedmiotach sprowadzanych lub znajdujących się na tykocińskim zamku, także za Jana Klemensa III. Istnieją jedynie przekazy mówiące o naczyniach przez niego zamawianych bądź stanowiących wyposażenie innych jego siedzib, przede wszystkim pałaców w Białymstoku, Warszawie i Choroszczy. Dokumenty te stanowią jednak cenne 
źródło wiadomości o asortymencie należących do hetmana wyrobów fajansowych i porcelanowych, ich liczbie, przeznaczeniu i proweniencji, o preferencjach właściciela co do rodzajów, ornamentyki i kolorystki naczyń. Czy któreś z nich dotarły do Tykocina i były tu używane przy bardziej uroczystych okazjach? Prawdopodobnie tak, na co wskazują opisane wyżej znaleziska, tym bardziej, że w 2. połowie XVII wieku Tykocin był miejscem częstych pobytów właścicieli. Tutaj, aż do końca XVIII wieku, znajdował się główny port dla dóbr podlaskich, skąd spławiano produkty rolne. Docierały do niego także wszelkie towary transportowane drogą wodną z portów nadbałtyckich i ze stolicy (Sztachelska-Kokoczka 1991, s. 214 i nn.; 1997, s. 15). Zamek mógł stanowić nie tylko punkt docelowy dla sprowadzanych artykułów (w tym ceramiki), ale także ich magazyn, skąd następnie przewożono je do innych podlaskich siedzib Branickich.

Źródła pisane informują, że w latach około $1752-1760^{31}$ do Jana Klemensa III należały między innymi wymienione w tytule „trzy puzdra ${ }^{32} \mathrm{z}$ kaftiorami”, tj. pudła, w których przechowywano serwisy do kawy i herbaty ${ }^{33}$. Pierwsze z nich mieściło białe, „wyzłacane” naczynia z chińskiej porcelany, w tym imbryki, "flaszkę na suchą herbatę", cukiernicę, filiżanki, spodeczki i wazki do ich płukania (łącznie 20 naczyń) oraz srebrne łyżeczki i szczypce do cukru. Pozostałe dwa puzdra zawierały podobne zestawy miśnieńskie - jeden „biały, suto wyzłacany”, drugi „,biały, złocony i malowany” (Kowecka 1991, s. 218). W 1. połowie XVIII wieku podobne sprzęty (skrzynie, szkatułki, obite skórą, wyściełane atłasem lub aksamitem), w których przewożono porcelanowe lub fajansowe podróżne komplety naczyń, posiadali inni magnaci, na przykład Jan Angary Czapski (w 1725 roku) i Jan Jerzy Przebendowski (w 1730 roku) (Wendland 2008, s. 212).

Wiadomo, że hetman, przez swojego plenipotenta, zamawiał znaczą liczbę tych wyrobów w Warszawie. Był stałym klientem tamtejszego składu miśnieńskiej porcelany, w którym systematycznie dokonywał zakupów (na przykład w latach 1752-1760 niemal co roku) (Kowecka 1991, s. 216, 218, przypis 184) ${ }^{34}$. Zaopatrywał się tam w rozmaite naczynia, zarówno prostsze, jak i bardziej ozdobne, między innymi talerze płytkie i głębokie, kubki, filiżanki (zazwyczaj bez uszek), jak również cukierniczki, musztardniczki, „koszyki do pomarańcz”. Mimo, że stanowiły produkty renomowanej wytwórni, ich jakość być może była zróżnicowana, niekiedy bowiem nie spełniała oczekiwań Branickiego (Kowecka 1991, s. 218).

${ }^{31}$ W publikacji E. Koweckiej (1991, s. 218) wzmianka ta nie jest datowana. Na podstawie informacji zamieszczonych w przypisie 184 można przypuszczać, że pochodzi z tego właśnie okresu.

32 Puzdro - pudło z przegródkami lub wklęsłościami różnego kształtu, dostosowane do przechowywania różnych przedmiotów; futerał (Stownik Staropolski 1976, s. 409).

33 Takie serwisy (komplety) zwano ,garniturami”; w ich skład wchodziły filiżanki, imbryczki, cukierniczki, dzbanuszki do mleka lub śmietanki, niekiedy też wazy do płukania filiżanek (Wendland 2008, s. 210).

${ }^{34}$ Skład fabryczny manufaktury miśnieńskiej w Warszawie był czynny od 1731 do 1796 roku (Chrościcki 1974, s. 16). 
Porcelanę miśnieńską hetman kupował z reguły na sztuki, wybierając egzemplarze z podobną dekoracją, na przykład „w kwiaty błękitne”, czyli z popularnym motywem zdobniczym, długo stosowanym w tej wytwórni. Nabywał też wyroby innych, zachodnioeuropejskich manufaktur ceramicznych $-\mathrm{z}$ Wiednia ${ }^{35}$ i Strasburga $^{36}$. Zakupów tych dokonywał przez warszawskiego bankiera Teppera, który handlował także innymi farfurami. Z roku 1749 pochodzi informacja, że ,garnitur” fajansowy ze strasburskiej fajansarni ma zostać wkrótce dla niego sprowadzony (Kowecka 1991, s. 218, przypis 185). Z kolei „nowa” porcelana wiedeńska (łącznie 24 naczynia - salaterki i wazki na konfitury) została dostarczona do Warszawy w 1763 roku. W posiadaniu Branickiego było wiele naczyń pochodzących z Wiednia, których używano zarówno podczas głównych posiłków, jak i „do wetów” (czyli do deserów). Do tego ostatniego celu służył między innymi serwis „dawny”, wówczas składający się z ponad setki rozmaitych naczyń, w większości o ściśle określonym przeznaczeniu. Prócz stanowiących większość talerzy w skład kompletu wchodziły także kompotierki, czarki do konfitur i do mleka, kubki do wina, pary filiżanek do czekolady, „muszelki”, kubki z przykrywkami „do zamrażania” (zapewne do sorbetów) i „kosze do fruktów” (Kowecka 1991, s. 219). Z Wiednia pochodziły też liczne filiżanki o zróżnicowanej wielkości i ornamentyce (34 pary, w tym z wyzłacanym brzegiem, z różowymi uszkami, w kwiaty), znajdujące się wówczas w warszawskiej i białostockiej rezydencji. Przeznaczone były do spożycia kawy, herbaty i czekolady. Z kolei porcelanowe dzbanuszki służyły „do kwiatków” (Kowecka 1991, s. 216). Wszystkie te przedmioty, zarówno figurki, jak i naczynia, zdobiły pałacowe wnętrza, ustawiane były na gzymsach kominków, stoliczkach i konsolkach (Kowecka 1991, s. 71). Niektóre wyroby ulegały stłuczeniu, co także znalazło potwierdzenie w korespondencji hetmana ${ }^{37}$.

Dużo naczyń (jednorazowo po kilka, kilkanaście tuzinów) kupowano dla Branickiego także w Gdańsku i Królewcu, na przykład w latach 1754, 1759, 1766-1768. Te wyroby określane były w źródłach jako „ordynaryjne” (zapewne pośledniej jakości, niezdobione), niekiedy „ordynaryjne przednie”. Malowane talerze fajansowe i gliniane opisywano jako „gdańskie”. Pod tym terminem kryją się prawdopodobnie wyroby z tzw. fajansu pomorskiego. Sprowadzano także „farfurki płytkie holenderskie”, tj. najpewniej niezbyt głębokie talerze, pochodzące z wytwórni niderlandzkich. Proweniencja pozostałych nie została określona (Kowecka 1991, s. 219, przypis 187).

\footnotetext{
${ }^{35}$ Manufaktura porcelany we Wiedniu działała w latach 1717-1869. W 1771 roku otwarte zostały dwa sklepy fabryczne na terenie Polski - we Lwowie i Berdyczowie (Chrościcki 1974, s. 129-131). Natomiast przedmioty fajansowe wytwarzano w Wiedniu systemem rzemieślniczym (Chrościcki 1989, s. 99).

36 Wytwórnia w Strasburgu (Strasbourgu) działała w latach 1721-1786; produkowano tam przedmioty z fajansu i porcelany (Chrościcki 1984, s. 113).

${ }^{37} \mathrm{Na}$ przykład miśnieńskie wyroby porcelanowe sprowadzane do Białegostoku z magazynu w Warszawie (Kowecka 1991, s. 218).
} 
Wyroby z fajansu i porcelany dotychczas dość rzadko były przedmiotem zainteresowania archeologów (Oniszczuk-Rakowska 2002; 2005; Marcinkowski 2011; Kwiatkowski 2011; 2012; Sieńkowska 2009; Więcek 2012). Studia nad tymi wyrobami stanowią na ogół domenę historyków sztuki, dla których przedmiotem opracowań są eksponaty muzealne najlepiej zachowane oraz najefektowniejsze. Natomiast materiały pozyskane w czasie badań archeologicznych, zależnie od miejsca ich zdeponowania, mogą być w różnym stopniu rozdrobnione. Warto jednak zwrócić uwagę na te znaleziska, na tkwiące w nich możliwości interpretacyjne oraz ich znaczenie, także jako datowników archeologicznych. Te delikatne i kruche przedmioty to także między innymi materialne świadectwa zamożności właścicieli, ich podążania za obyczajami i trendami w modzie, jakich wymagała pozycja społeczna i wystawny tryb życia. Były to także akcesoria niezbędne do spożywania nowych wówczas napojów. Występujące na nich elementy zdobnicze stanowią odbicie stylów dekoracyjnych, powszechnych w różnych dziedzinach rzemiosła i sztuki w nowożytnej Europie.

\section{BIBLIOGRAFIA}

Źródła

Regestr Szkod Uczynionych $\quad-\quad$ Regestr Szkod Uczynionych tak w Mieście Tykocinie [...] przez kupy Swawolne Ludzi Mazowieckich [...] A $\mathrm{A}^{\circ} 1734$ Spisany [...], Archiwum Główne Akt Dawnych w Warszawie, Archiwum Roskie.

Literatura

Balicka-Knotz R.

$2000 \quad$ Fajans w zbiorach Muzeum Okręgowego w Rzeszowie, Rzeszów.

Baranowski J.

1991 Walory historyczne i ekspozycyjne zabytków Tykocina, Rocznik Białostocki, t. 16 , s. 59-75.

Benini M., Cerutti C., d'Agliano A., Vianello G.

1998 Ceramika XV-XX wieku, Warszawa.

Birkenmajer E.

1979 Fajanse z Nevers w zbiorach wilanowskich, Studia Wilanowskie, nr 5, s. 59-67.

1992 Fajans europejski XVI-XX w., Gdańsk.

Bis M., Bis W.

2006 Archeologia na zamku w Tykocinie - problemy i postulaty badawcze, [w:] Stan badań archeologicznych na pograniczu polsko-białoruskim od wczesnego średniowiecza po czasy nowożytne, red. H. Karwowska, A. Andrzejewski, Białystok, s. 221-230. 
Choińska M.

2009/2010 Powinności mieszczan $w$ mieście królewskim a $w$ mieście prywatnym: przykład Tykocina w XVI-XVIII wieku, Studia Podlaskie, t. 18, s. 7-110.

Chojnacka H.

1981a Fajanse polskie XVIII-XIX wieku, Warszawa.

1981b Polska porcelana 1790-1830, Warszawa.

Chrościcki L.

1974 Porcelana - znaki wytwórni europejskich, Warszawa.

1989 Fajans. Znaki wytwórni europejskich, Warszawa.

Diviš J.

1984 Europäisches Porzellan, Praha.

Encyklopedyja

1867 Encyklopedyja Powszechna Orgelbranda, t. 25, Warszawa.

Först E.

2006 Zerbrochen und weggeworfen, [w:] Der Hamburger Hafen - das Tor zur Welt im Spiegel archäologischer Funde, red. R.-A. Weiss, Hamburg, s. 39-73.

Holl I.

2005 Fundkomplexe des 15.-17. Jahrhunderts aus dem Burgpalast von Buda, Budapest.

Karwowska I.

2010 Uwagi na temat biatej ceramiki (Stettiner Ware) jako charakterystycznego wyrobu garncarzy pomorskich w XVIII i XIX wieku, [w:] I. Karwowska, Biała ceramika szczecińska ze zbiorów Muzeum Narodowego w Szczecinie, Szczecin, s. 17-20.

Kilarska E.

1981 Dalekowschodnie motywy figuralne na ceramice pomorskiej $w$ drugiej ćwierci XVIII wieku, Gdańskie Studia Muzealne, t. 3, s. 83-105, s. 343-354.

2003 Fajanse z Delft w dawnym Gdańsku, Gdańsk.

Kowecka E.

1991 Dwór ,najrządniejszego w Polszcze magnata”, Warszawa.

Kowecka E., Łosiowie M. i J., Winogradow L.

1983 Polska porcelana, Wrocław.

Klarecki M.

2012 Porcelanowe i fajansowe zabytki z XVIII wieku odnalezione podczas wykopalisk archeologicznych w ruinach dawnego Banku Polskiego, Warszawskie Materiały Archeologiczne, t. 10, s. 110-119.

Kluczwajd K.

2003 Kruche piękno. Ceramika europejska ze zbiorów Muzeum Okręgowego $w$ Toruniu, Toruń.

Kwiatkowski K.

2011 Niderlandzkie talerze fajansowe z motywami biblijnymi z badań archeologicznych kwartału IX w Stargardzie, Stargardia, t. 6, s. 223-250.

2012 Manufaktura stylów - wyroby fajansowe z badań w Stargardzie, Stargard. 
Łopatecki K.

2009 Plan przebudowy twierdzy w Tykocinie z 1708 roku, Zapiski Historyczne, t. 74, z. 2, s. 63-76.

Marcinkowski M.

2011 Fajans pomorski ze Starego Miasta w Elblagu, Elbląg.

Maroszek J.

$2000 \quad$ Pogranicze Litwy i Korony w planach króla Zygmunta Augusta. Z historii dziejów realizacji myśli monarszej między Niemnem a Narwia, Białystok.

Melegati L.

1997 Ceramika. Dzieje terakoty, majoliki, kamionki, porcelany, fajansu, od starożytności po czasy wspótczesne, Warszawa.

Oniszczuk-Rakowska A.

2002 Ceramika nowożytna z latryn posesji przy ulicy Szklary 2-5 w Gdańsku, [w:] Dominikańskie Centrum Św. Jacka w Gdańsku. Badania archeologiczne, t. 2, red. A. Gołembnik, Warszawa, s. 207-272.

2005 Uwagi o stanie badań nad nowożytna ceramika szlachetna w Polsce, wraz $z$ katalogiem naczyń pewnie datowanych, pochodzacych z badań prowadzonych na terenie przyszłego Centrum Dominikańskiego w Gdańsku, Monument. Studia i Materiały Krajowego Ośrodka Badań i Dokumentacji Zabytków, nr 2, s. 525-540.

Piątkiewicz-Dereniowa M.

1991 Artystyczna ceramika europejska w zbiorach polskich, Warszawa.

1996 Fajanse z Delft w zbiorach Zamku Królewskiego na Wawelu, Kraków. Polski fajans

2004 Polski fajans w zbiorach Muzeum Zamkowego w Malborku. Katalog, oprac.

U. Jastrzembska, Malbork.

Rada P.

1993 Techniki ceramiki artystycznej, Warszawa.

Rudzki E.

1981 Europejska porcelana osiemnastowieczna, Warszawa.

Sieńkowska U.

2009 Naczynia fajansowe z Delft z badań archeologiczno-architektonicznych Starego Miasta Elblaga, Elbląskie Studia Muzealne, t. 1, s. 159-168.

Stownik

1892 Stownik geograficzny Królestwa Polskiego i innych krajów słowiańskich, Stownik Staropolski red. B. Chlebowski, t. 12, Warszawa, s. 695-698 (hasło - Tykocin).

1976 Stownik Staropolski, red. S. Urbańczyk, t. 7, z. 6(46), Warszawa. Starzewska M., Jeżewska M.

1978 Polskifajans, Wrocław.

Szarek I.

2003 W świecie porcelany... Stara ceramika europejska i orientalna w kolekcji Ireneusza Szarka. Katalog wystawy 18 listopada 2003-18 stycznia 2004, Warszawa. 
Szelegejd B.

2007 Ceramika europejska. Galeria rzemiosta artystycznego, Warszawa.

Szkurłat A.

2011 Manufaktura porcelany i fajansu w Korcu, Warszawa.

Sztachelska-Kokoczka A.

1991 Organizacja i struktura spławu produktów z dóbr Jana Klemensa Branickiego do Gdańska w XVIII wieku, Rocznik Białostocki, t. 17, s. 213-237.

1997 Spław produktów z dóbr Jana Klemensa Branickiego, Białostocczyzna, nr 4(48), s. 15-20.

Trzebiński W.

1955 Ze studiów nad historia budowy miast prywatnych w Polsce wieku Oświecenia, Studia z historii budowy miast, Prace IUA, R. 5, z. 1/14, s. 92-100 (Tykocin).

Wedgwood

2002 Wedgwood. Ceramika XVIII-XX wieku z kolekcji Wedgwood Museum Trust w Barlaston, Potteries Museum \& Art Gallery w Stoke-on-Trent, Nottingham Castle Museum \& City Gallery oraz ze zbiorów polskich, red. W. Załęska, Warszawa.

Wendland E.

2008 Kawa, herbata i czekolada. Nowe napoje XVIII-wiecznej Rzeczypospolitej - ich wplyw na życie codzienne, Torun.

Więcek E.

2012 Kuchnia i jadalnia zamożnych mieszkańców XVIII-wiecznej Warszawy, Warszawskie Materiały Archeologiczne, t. 10, s. 88-109.

Zielińska T.

1997 Poczet polskich rodów arystokratycznych, Warszawa.

2006 Klientela w otoczeniu Jana Klemensa Branickiego kasztelana krakowskiego $i$ wielkiego hetmana koronnego około połowy XVIII wieku, [w:] Patron i dwór. Magnateria Rzeczypospolitej w XVI-XVIII wieku, red. E. Dubas-Urwanowicz, J. Urwanowicz, Warszawa, s. 209-223.

\section{„,THREE CASES WITH COFFEE-POTS...”, IT IS ABOUT FAIENCE AND PORCELAN IN TYKOCIN CASTLE}

Summary

Archaeological explorations carried out so far in the castle area in Tykocin - Podlachia, have delivered not only numerous, but also varied movable artifacts. Despite predominating objects of local production, there are also items from distanced production centers; these are, among the others, fragments of glass vessels, clay pipes, elements of armory and coins from $16^{\text {th }}$ century up to $19^{\text {th }}$ century. The article concentrates on two selected categories of modern imports and their local imitations, i.e. porcelain and faience.

For 91 thousand of various source categories obtained in the discussed site, pieces of faience and porcelain create relatively small collection of 614 fragments, including 540 pieces of faience and 74 pieces of porcelain. The minimum number of those vessels 
was defined for 304, respectively: 251 and 53 items. Nearly half of all the fragments was obtained from mixed layers, made chiefly as a result of architectonic works, performed in the castle and around in the 60 s of the last century.

Most of the production was unsigned, therefore it is rather difficult in defining the objects' origin and precise dating. Only ten vessels are marked (five porcelain and five faience ones), seven of which created possibilities of identification. Production places of majority of items were stated on the base of manufacturing techniques and comparative analyses. It was possible first of all for ornamented examples with decorative elements characteristic for particular workshops, production centers on vessel types. This collection consists, among the others, of the most expensive and the most desirable products of those times - original China, Dutch faiences of Delft, English dishes from Josiah Wedgwood's manufacture(?) and porcelain from Meissen of Saxony and royal Vienna manufacture, but moreover - products probably from workshops situated in Italy, England (Bristol), France (Nevers, Rouen, Sèvres), other German centers (Volkstedt), Silesia (Prószków Śląski), Volhynia (Korzec, Baranówka, Horodnica), Pomerania (Gdańsk, Szczecin area) and Lesser Poland (Ćmielów, Iłża). The listed finds are mainly elements of crockery sets - plates, saucers, bowls, cups, soup tureens and vases, pitchers. The collection is completed by a tea-pot and lids (probably for jugs). Tykocin assembly also possesses one sanitary vessel - a bed-pan. The assortment of faience products is more diversified, in comparison with more unified porcelain collection, although in both ceramic groups - plates are in predominance.

The described artifacts is an interesting material evidence of needs and aesthetic preferences of the buyers, new trends in ceramic manufacturing of the period and consumption fancies, the proof of fulfilling the orders and active commodity exchange between Tykocin and the Baltic towns, as well as the capital in modern period. As far as kinds and ornamentations are concerned, the products refer to common trends in West European and home ceramic production from the end of $17^{\text {th }}$ century up to $19^{\text {th }}$ century.

Majority of the described products, both porcelain and faience ones were used when the castle was owned by the last two Branicki Family representatives - Stefan Mikołaj (about 1640-1709) and Jan Klemens III (1689-1771). It can not be excluded, that some of these objects were brought to the castle in the beginning of $18^{\text {th }}$ century together with Polish of foreign monarchs' courts. On the base of historic evidence existing we have only information on the movable property of Jan Klemens III, but there is lack of information concerning the objects belonging to his father. There are no direct remarks about the objects brought or being in possession of Tykocin castle residents; there are only notices saying about dishes ordered by the hetman or belonging to the equipment of his other seats, first and foremost, the palaces in Białystok, Warsaw and Choroszcza. However, these documents deliver precious information on the assortment belonging to Jan Klemens III and consisting of faiences and porcelain, their quantity, origin and destination, the owner's preferences as to types, ornaments and colors of the preferred vessels. It can be speculated that some of those objects reached Tykocin and were used here during more ceremonious occasions. 
